\title{
Diagnostic significance and prognostic role of the ARID1A gene in cancer outcomes (Review)
}

\author{
EVANGELIA N. PAVLIDOU ${ }^{1,2}$ and VASILEIOS BALIS ${ }^{2}$ \\ ${ }^{1}$ Covance Clinical and Periapproval Services Ltd., Harrogate, North Yorkshire HG3 1PY, UK; \\ ${ }^{2}$ AMC Metropolitan College, 54624 Thessaloniki, Greece
}

Received October 29, 2019; Accepted January 29, 2020

DOI: $10.3892 /$ wasj.2020.37

\begin{abstract}
Mutations of the ARID1A gene, which encodes the basic directional subunit of SWI/SNF chromatin remodeling complexes, were detected in the middle of the last decade in several cancerous tissue types, highlighting its tumour-suppressive role. Since then, functional studies of the homologous protein have indicated that through its interactions with nucleosomal DNA, transcription factors and nuclear hormone receptors, it plays a key role in regulating cellular proliferation, gene expression and the repair of genetic material, while the loss of its expression triggers carcinogenesis, through mechanisms which have not yet been elucidated. This bibliographic review of clinical investigations focused on the detection of ARID1A mutations and expression levels in malignant tumours, as well as on their association with the prognosis of ARID1A-deficient patients exhibiting a high degree of heterogeneity in the corresponding research findings. The clarification of the prognostic significance of the gene requires further investigation, focusing on cancers and patients of common clinicopathological features.
\end{abstract}

\section{Contents}

1. Introduction

2. Summary of the materials and methods used for analysis in previous studies

3. Summary of the findings of previous studies regarding ARID1A in cancer

4. Discussion

5. Conclusion and future therapeutic perspectives

Correspondence to: Dr Vasileios Balis, AMC Metropolitan College, 14 El. Venizelou Street and Tsimiski, 54624 Thessaloniki, Greece

E-mail:vbalis@mitropolitiko.edu.gr

Key words: ARID1A, SWI/SNF, chromatin remodeling, tumour suppressor gene, prognosis, carcinogenesis

\section{Introduction}

The ARIDlA gene. The AT-rich interactive domain-containing protein 1A (ARID1A) gene is located on chromosome 1p36.11, a genetic site often found to be deleted in a wide range of human cancers (1). It contains 20 exons and encodes two functionally identical 2285 and 2086 amino acid isoforms of the ARID1A protein, also known as Brahma-related associated factor 250a (BAF 250a), SWI/SNF-related matrix-associated actin-dependent regulators of chromatin factor 1 (SMARCF1) or p270 $(2,3)$. ARID1A is a large nucleocytoplasmic protein of $250 \mathrm{kDa}$, expressed in almost all tissues, whose stability depends on its cellular location (4-6). Nuclear ARID1A is significantly more unstable than its cytoplasmic counterpart, as it degrades rapidly, dependent on the ubiquitin-proteasome system of the nucleus, demonstrating significant fluctuations of expression during the cell cycle (4). Normally, the accumulation of the produced protein is detected during the G0-G1 phase of the cell cycle, while a strong reduction occurs during the $\mathrm{G} 2-\mathrm{S}$ phase (7).

The first significant evidence showing correlation between tumourigenicity and the reduced expression of ARID1A protein emerged in the middle of the past decade as the result of a cancer profiling array containing complementary cDNA from various tumour tissue cells and simultaneous northern, Southern and western blot analyses of several human cancer cell lines (6). In 2010, two next generation sequencing-based studies of highly aggressive ovarian cancers revealed a high frequency of inactivating ARID1A mutations $(8,9)$, thus initiating further investigation and confirmation of its reliable (bona fide) tumour suppressor role in a wide range of malignancies (10-13). Nowadays, it is considered that inactivating mutations of the gene affect the biological behaviour of tumours; hence, recent clinical studies examine their prognostic impact on the clinical outcome of cancer (14).

ARIDIA protein and SWI/SNF complexes. ARID1A is a member of a large family of proteins that contain a characteristic ARID domain of approximately 100 amino acids, which binds DNA fragments rich in adenine-thymine (AT) and was originally discovered in 1995 in the Drosophila dead ringer protein and in the murine B cell-specific transcription factor Bright (5,15-17). Later, researchers demonstrated the presence of at least fourteen human homologous proteins, without 
sequential specificity requirement during DNA binding, including the ARID1A and the encoded by the paralog gene ARID1B protein, that are mutually exclusive, found in cells at a 3.5:1 ratio, basic subunits of the BAF subfamily of human switching mate/sucrose non-fermenting (SWI/SNF), ATP-dependent chromatin remodeling complexes (6,17-19).

Phylogenetically conserved SWI/SNF protein complexes, whose name derives from the type of yeast Saccharomyces cerevisiae in which they were discovered $(20,21)$, are employed by transcriptional activators of the genes in order to reconstruct chromatin and break its structural constraints that prevent transcriptional proteins from accessing the genome (22-25). Using the energy released from the hydrolysis of ATP, the SWI/SNF mobilize histone octamers and interrupt their interactions with nucleosomal DNA, releasing the transcribed part of the helix (26-29), while altering the sensitivity of the restructured nucleoprotein to the digestive activity of nucleases (30) and enhancing the affinities of the gene promoters with the TATA-box-binding-protein (TBP) and the basic translation machinery (31). The role of SWI/SNF is considered to be critical for the regulation of gene expression, cellular proliferation, apoptosis, differentiation and the repair of genetic material (32-34).

The majority of the one hundred members of the hSWI/SNF family, alias BAF or SMARC, depending on the type of cell in which they are contained, may consist of combinations of 8-15 protein subunits and their isoforms, encoded in total by 26 genes, whose mutations were found to be involved in $20 \%$ of all human cancers $(19,23,32,35-38)$. The main structural feature and catalytic trunk of the complexes is the ATPase, belonging to the superfamily II of helicases that converts the chemical energy of one hydrolysed ATP molecule into mechanical motion of $1 \mathrm{bp}$ step along the DNA double helix $(2,24,39)$. Based on the type of helicase, BRM (SMARCA2) or BRG-1 (SMARCA4), by $74 \%$ identical to each other, hSWI/SNF are divided into two corresponding subfamilies: hSWI/SNF-A (BAF) and hSWI/SNF-B (PBAF) (2,40-42).

ARID1A is the largest, non-catalytic BAF subunit, with the main property of conferring target specificity on the complex and directing the ATPase activity, as the ARID domain binds across to at least $50 \mathrm{bp}$ of specific nucleosomal DNA constituting the origin of chromatin remodeling $(21,40,43,44)$. Its guiding effect, according to the prevailing theory, is attributed on the one hand to the interactions of the protein with the transcription factors, the hormone nuclear receptors and the p53, p21 (CDKN1A), SMAD3 proteins, via the C-terminal peptide-rich binding loci (LXXLL-leucin rich motifs), while on the other hand to the ARID domain-mediated high affinity between chromatin and SWI/SNF $(4,36,40,45,46)$. Recently, ARID1A has also been found to be indirectly involved in the modification of histones, by binding to histone H2B as E3 ligase of ubiquitin (23).

Epigenetic regulation of ARIDIA expression in physiological cell processes. Effective cellular homeostasis, normal development and tissue-specific differentiation in multicellular organisms require the translation of the same genotype into different phenotypes and depend on the epigenetic regulation of gene expression, that determines the cell identity and establishes heritable, not associated with the DNA sequence expression patterns through a complex system of mechanisms, including DNA methylation, histone modifications and miRNA inhibition (47-49). Although the cell-specific molecular mechanisms mediating transcriptional responses to environmental and developmental signals remain poorly understood, ARID1A as a cell cycle regulator that affects cell growth and differentiation, undergoes spatial and temporal epigenetic modifications, depending on the cell type and the developmental process $(50,51)$.

Sun et al previously reported that ARID1A protein was absent in neonatal mouse liver until the tenth day of life, thus allowing rapid cell proliferation, while its expression was physiologically downregulated following surgically- and chemically-induced injuries in mouse models, promoting liver regeneration and ear hole wound healing (52). Similar to tissue regeneration, embryonic development requires unique gene expression patterns that facilitate the reorganization of tissue structural design (53). In fact, the presence of ARID1A protein in the nucleus of mouse embryonic stem cells has been proven to be essential for their differentiation, pluripotency and early germ-layer formation, by coordinating the expression of key developmental and pluripotent genes $(54,55)$. Similarly, Han et al demonstrated that the universal expression of ARID1A across different lineages of mouse hematopoietic stem cells was determinant for their frequency and function, regulating the production of mature blood cells, while the gene expression was relatively lower in mature myeloid cells (56). As regards mouse cardiogenesis and cardiac progenitor cell differentiation, distinct gene expression patterns have been observed for BAF complex subunits (57). Specifically, ARID1A has been shown to be expressed to a great extent in the early developing heart, in order to selectively control the differentiation of second heart field cardiac progenitor cells into beating cardiomyocytes, although it is downregulated during the development and initiation of cardiac trabeculation (58). Furthermore, the epigenetic regulation of ARID1A in response to DNA damage seems to play a key role in DNA repair and genome integrity maintenance. As a matter of fact, ARID1A appears accumulated in DNA double-strand breaks sites, recruited through its interactions with the ataxia telangiectasia and RAD3-related protein (ATR), in order to support and diffuse damage signals within mammalian cells, and enable the access of the non-homologous end joining (NHEJ) pathway-related repair proteins to the break sites $(59,60)$.

Abnormal epigenetic regulation of ARIDIA expression. Wiegand et al detected the loss of ARID1A expression, not attributable to gene mutations in $11 \%$ of ovarian clear cell carcinomas and $9 \%$ of endometrioid carcinomas, raising a matter of epigenetic silencing (9), which also leads to deviated chromatin remodeling, and subsequently to the deregulated expression of 99 target genes involved in carcinogenesis (61). Considering that almost $40 \%$ of the human gene-promoters incorporate regions of several $\mathrm{kb}$, rich in cytosines preceding guanines commonly called $\mathrm{CpG}$ islands, whose methylation carried out by DNA methyltransferases (DNMTs) represses transcription $(62,63)$, it is not surprising that among the known epigenetic mechanisms, the altered patterns of DNA methylation silencing established tumour suppressor genes have been recognised as a consistent molecular characteristic 
of human tumours since 1991, and are currently regarded as the most important epigenetic mark, critically involved in tumourigenesis (64-67).

Aiming to investigate the underlying reasons for the ARID1A low mRNA expression in invasive breast cancers, Zhang et al demonstrated that it was not associated with genetic alterations and reported that $86.45 \%$ of low expression patients exhibited a $>2$-fold aberrant increase in ARID1A promoter methylation, often accompanied by repressive histone modifications, while in $81.8 \%$ of patients with a high expression, the promoter methylation was found to be decreased 2-fold (68). The key role of DNA hypermethylation in ARID1A protein loss during gastric cancer progression was demonstrated by the fact that the de-methylation of gastric cancer cell lines restored the expression of ARID1A (69), while a recent study, focusing on decreased ARID1A expression during the pathogenesis of endometriosis, revealed that oxidative stress stimulates the expression of DNMT1 and causes ARID1A downregulation due to promoter hypermethylation (70). In the opposite direction, ARID1A promoter was found to be unmethylated during the investigation of its methylation status in The Cancer Genome Atlas (TCGA) Illumina Infinium dataset from 50 representative clear cell renal cell carcinomas (ccRCCs), drawing the attention towards other mechanisms of epigenetic silencing (71).

Concerning the suppressed ARID1A expression in ccRCC, a recent study identified ARID1A as a direct downstream target of microRNA (miRNA or miR)-144-3p, whose upregulation provoked a significant decrease in ARID1A mRNA and protein levels (72). miRNAs were identified for the first time in 1993, as non-coding RNA molecules that regulated larval transition and neuronal development in Caenorhabditis elegans (73). Since then, these small RNAs consisting of approximately 21-25-nucleotides have been known to repress gene expression at the post-transcriptional level through direct interactions with specific target mRNAs, to regulate various developmental and physiological cellular processes via different expression patterns (74) and when abnormally expressed, to function as oncogenes or tumour suppressors, depending on the cellular circumstance and the function of their target genes (75).

Further studies have highlighted the implications of overexpressed miRNAs targeting ARID1A by binding to its 3' untranslated region (3'UTR). The investigation of the strong association between Helicobacter pylori (H.Pylori) infection and gastric carcinogenesis indicated that the H. Pylori virulence factor CagA triggers the nuclear factor (NF) $-\kappa B$ pathway and stimulates the expression of miR-223-3p, which in turn functions as an oncomiRNA by downregulating ARID1A (76). Two studies have reported the ARID1A-associated oncogenic action of miR-31. The first one demonstrated that the early upregulation of miR-31 due to EGFR activation in head and neck squamous cell carcinoma (HNSCC) caused enhanced oncogenicity and stemness by directly targeting ARID1A and inhibiting its expression (77), while the second identified miR-31 high levels as the cause of ARID1A silencing in cervical cancer cell lines and tissues (78). Yang et al also studied cervical cancer tissues and detected the presence of significantly increased miR-221 and miR-222 that simultaneously bind to the ARID1A 3'UTR and inhibit its expression, thus inducing cancer cell proliferation and invasion (79). Of note, the findings of $\mathrm{Li}$ et al described an inverse regulatory axis of events, suggesting that the loss of the expression of ARID1A in pancreatic cancer cells upregulates miR-503, which in turn inhibits cell senescence and promotes mutant KRASG12D induced tumourigenesis by targeting another cell cycle regulator, the cyclin dependent kinase inhibitor $2 \mathrm{~A}$ (CDKN2-A) (80).

ARIDIA: Mutational profile and tumour suppressing role. A total of $97 \%$ of inactivating ARID1A somatic mutations that lead to the reduction or complete loss of protein expression are nonsense, point and insertion or deletion frameshift mutations, distinctive of tumour suppressor genes, that have been found to be distributed throughout its length $(3,9,12,13)$. The consequential abnormal mRNA often carries premature stop codons and is translated into a truncated protein, functionally degraded, either due to misfolding or as it is partially incomplete, resulting in the disturbance of the normal levels of nuclear ARID1A and the destabilization of SWI/SNF complexes (46,81-83). Mutations of tumour suppressor genes usually include alterations in both alleles. However, in the case of ARID1A, one allele mutation is sufficient to cause the loss of ARID1A expression in the majority of heterozygous tumours, thus indicating genetic haplodeficiency $(3,8,10)$.

Fig. 1 illustrates the effects of the loss of ARID1A expression and its impact on carcinogenesis, although the precise mechanisms that triggers cancer development have not yet been fully elucidated. ARID1A expression disorders disrupt the function of SWI/SNF and the chromatin remodeling mechanism, causing epigenetic abnormalities in gene expression with severe consequent effects in the cell identity and possible carcinogenicity (41,84-86). In addition, functional studies of ARID1A have demonstrated that its tumour-suppressive action lies both in the control of cellular proliferation and in maintaining the integrity of the genetic material, which is why both roles of guardian and caretaker of the genome are attributed to it $(3,13)$.

As regards the regulation of cell proliferation, experimental studies of a wide range of ovarian, endometrial, breast, stomach, liver and other cancer cell lines have demonstrated that the loss of ARID1A expression, either due to a mutation and epigenetic mechanism, or due to the in vitro silencing of the gene promotes tumour expansion, while the experimental restoration of the normal levels of the protein suppresses cancer cell proliferation $(11,13,87-90)$, confirming that cell cycle inhibition and differentiation requires a high concentration of ARID1A at the $G_{0}-G_{1}$ checkpoint (44). According to recent research findings, mutant ARID1A diverts cell proliferation by triggering the phosphatidylinositol 3-kinase $\mathrm{PI} 3 \mathrm{~K} /$ serine-threonine kinase AKT/mammalian target of rapamycin mTOR pathway (91-93), affects the expression of other cell cycle regulators, such as the c-MYC gene and promotes carcinogenicity in synergy with concurrent mutations of other tumour suppressors such as TP53, PTEN and SMARCB1 $(44,46,94)$ or oncogenes, such as PIK3CA $(95,96)$.

As a genome caretaker, ARID1A contributes to the prevention of chromosome and gene structural abnormalities through its direct interactions as a SWI/SNF subunit with topoisomerase II $\alpha$, which ensures the effective decatenation of sister chromatids during meiotic anaphase, thus preventing potential 


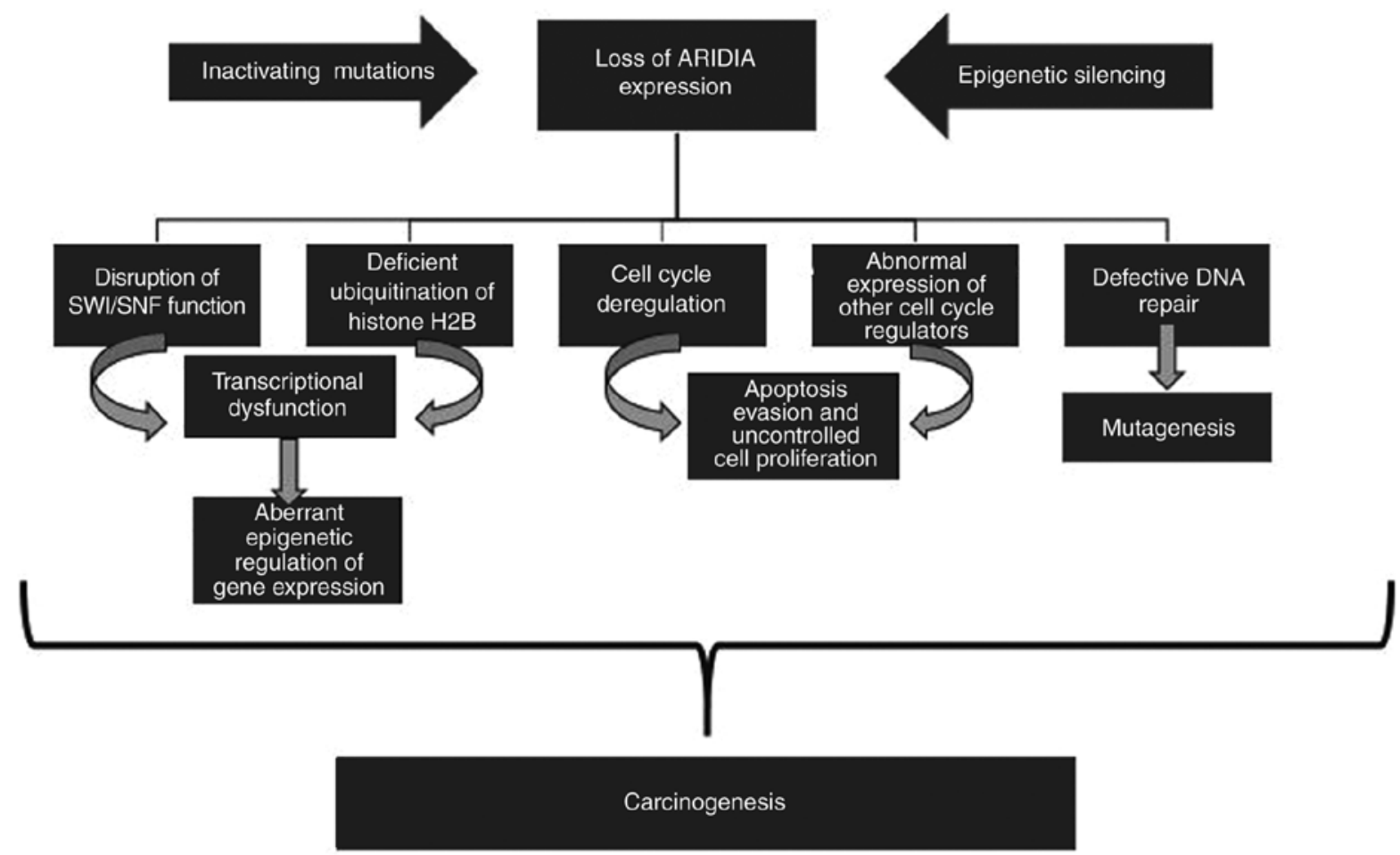

Figure 1. Loss of ARID1A expression and its impact on carcinogenesis. ARID1A inactivating mutations or epigenetic silencing cause expression disorders that suspend the tumour-suppressive role of the gene and trigger carcinogenesis via different mechanisms. The most prominent are the deviant chromatin remodeling due to disrupted SWI/SNF function or deficient ubiquitination of the histone H2B that divert gene transcription and lead to aberrant gene expression, the uncontrolled cell proliferation as a result of cell cycle deregulation, apoptosis evasion and abnormal expression of other cell cycle regulators, and the enhanced mutagenesis due to defective DNA repair. ARID1A, AT-rich interactive domain-containing protein 1A.

aneuploidies, polyploidies and sequence mutations (97). The contribution of the gene to DNA repair is considered to be equally important, as ARID1A is involved in the SWI/SNF recruitment of repair proteins, such as BRCA1 at the lesion sites (98), while the loss of its expression is significantly associated with microsatellite instability (MSI) in endometrial, gastric and colorectal cancers $(89,91,99,100)$.

Aims of this bibliographic review. Although the tumoursuppressive role of ARID1A is now considered to be unquestionable, the investigation of the mutant gene's diagnostic significance and prognostic role in the outcome of various malignancies, has yielded controversial results. It is indicative that the loss of protein expression occurs in $6.5 \%$ of patients with squamous cervical cancer and is associated with significantly reduced overall survival $(101,102)$, while it has no effect on the prognosis of patients with ovarian clear cell carcinoma, in which the gene mutation frequency reaches $55 \%(103,104)$. However, three recent meta-analyses of published studies on gastrointestinal $(81,105)$, gynaecological and urological cancers (11) present a general tendency to increased cancer-associated mortality in ARID1A protein-negative patients, in comparison to those who are positive, expressing the protein at normal levels. In particular, Luchini et al associated the loss of ARID1A with increased cancer-specific mortality following the meta-analysis of pooling data from three studies, one on gynaecological and two on urological cancers, while the gathered data from seven studies, five on gynaecological and two on urological cancers revealed no significant difference in cancer recurrence between ARID1A negative and positive patients (11).
Given that abnormalities in ARID1A expression affect both tumourigenesis and disease prognosis differently, this study has been based on the review of relevant research articles published in peer-reviewed journals, regardless of geographical origins. The aim was thus to record the incidence of inactivated ARID1A in human malignant tumours, to examine its diagnostic significance and to determine its prognostic value in the outcome of cancer, following a brief description of the most typical methods applied to detect protein expression abnormalities and gene mutations.

\section{Summary of the materials and methods used for analysis in previous studies}

Analytical samples. The samples mainly analysed by researchers were derived from contemporaneous or archived primary tumour resections, originating from cancer patients regardless of sex, nationality and age, whereas adjacent healthy tissue samples were used as negative controls. Basic prerequisites for inclusion were the identification of the histopathological type, the grading and the staging of the tumours, according to the World Health Organization classification (WHO), the TNM Staging System of the American Joint Committee on Cancer (AJCC) and the International Federation of Gynecology and Obstetrics (FIGO) guidelines in cases of gynaecological cancers, while the pre-excision subjection to chemotherapy or preoperative radiotherapy was the most frequently used exclusion criterion (106-113).

Depending on the method selected for the detection of ARID1A mutations and for the examination of protein 
expression in the cell nuclei, the majority of the samples were fresh-frozen tissues and formalin-fixed, paraffin-embedded histological preparations $(88,111,114,115)$, while in some cases as subject of the study were selected cancer cell lines of various tissues $(41,46,90,116)$. Exceptionally, the ARID1A expression levels in glioma patients were determined in blood serum due to the intracranial tumour (117).

Survival data. In order to investigate the prognostic role of the gene, the survival data of respective patients in previous studies were collected after clinical follow-up for an average of a five-year period $(102,107,117)$. Among the time parameters analysed were overall survival (OS), progression-free survival (PFS) and cancer recurrence, corresponding to the time interval from the date of diagnosis or ablation until up to documented death, to the noticeable worsening of the disease and to recurrent cancer diagnosis $(46,111,112,115,118)$.

Immunohistochemistry (IHC). The most commonly used methodology for controlling nuclear ARID1A expression in cancer tissues was found to be IHC, which was carried out by the deparaffinisation and rehydration of whole tissue sections or specific microarrays, 4-5- $\mu$ m-thick $(82,88,107,109,110,115,119)$. Usually, the preparations were initially immersed in antigen retrieval solution to amplify the imminent immune complex and after the endogenous peroxidase and the non-specific background were blocked, the tissues were incubated with primary, monoclonal mouse anti-ARID1A antibody or polyclonal rabbit anti-ARID1A, followed by secondary antibody labelled with horseradish peroxidase $(46,82,108,110-112,119)$. The immunoreactive signal was most frequently amplified with diaminobenzidine followed by competitive nuclear haematoxylin staining, while the evaluation and yield of the tissue immunoreactivity score were based on the percentage extent of the immunohistochemical expression and the intensity of staining of the ARID1A-positive nuclei $(41,108,110,115)$.

ARIDIA reverse transcription-quantitative PCR (RT- $q P C R)$ and western blot analysis. Along with the immunohistochemical method, the expression levels of ARID1A messenger RNA (mRNA) were also examined by RT-qPCR, following the isolation of total RNA from fresh tissues, most commonly using TRIzol reagent and following purification with the RNeasy mini kit $(82,88,111,118)$. RNA was processed with the TaqMan Reverse Transcription Reagents kit and RT-qPCR of the complementary DNA (cDNA) was performed on a $7900 \mathrm{H}$ Fast Real Time PCR System with a forward 5' $\rightarrow 3^{\prime}$ primer (CCCCTCAATGACCTCCAGTA) and a reverse $3^{\prime} \rightarrow 5^{\prime}$ primer (ATCCCTGATGTGCTCACTCC) $(88,107)$.

Equally common, for the validation of the IHC and RT-qPCR analyses, western blot analysis has been used to detect potential aberrations in ARID1A expression levels in cells, following extraction and measurement of cellular proteins by using the T-PER reagent and the BCA Assay kit, respectively $(46,88,107,116,118)$. Subsequently, in previous studies, polyacrylamide gel electrophoresis was performed in order to separate the proteins and transfer them to a nitrocellulose membrane where the immunoblotting was carried out using a primary anti-ARID1A antibody and a secondary horseradish peroxidase-labelled antibody $(46,118)$.
Sporadically and due to specific research requirements, additional laboratory methods have been used, such as high-performance liquid chromatography (HPLC) (117), cDNA microarrays (41), northern and Southern blot analyses (6).

Next-generation sequencing: The most sophisticated and specific approach. The genetic analyser Illumina Genome Analyzer II has been widely used in order to detect and accurately determine the profile of ARID1A mutations in cancer genomes by applying various NGS methods. Such methods are RNA sequencing (9), whole exome sequencing (WES) (120-122) and exome sequencing of specific genes (targeted NGS) $(8,106,107,114)$.

Most commonly, following homogenisation and the lysis of fresh tissue, genomic gDNA has been isolated using the Qiagen Blood and Cell Culture Mini kit and following qualitative examination by electrophoresis, it has been quantitated photometrically $(9,114,118)$. Using the DNA Sample Prep Reagent Set 1 kit, the enzymatic fragmentation of gDNA, multiplex PCR with T4 or Taq DNA polymerase and ligation of initiating (adapters) and sample-identifiability (barcodes) sequences at the ends of single-stranded fragments have been typically conducted by thermal cycling, in order to finalize the library according to the Illumina protocol and capture the coding sequences with the Human SureSelect All Exon kit $(8,107,114,122-124)$. The programs ExonPrimer and Primer3Plus have been utilised for the design of primers, whereas the PCR products have been purified with the ExoSAP-IT PCR Purification kit (114).

To complete the sequencing of the DNA libraries, new synthesis cycles have been performed by the addition of four reverse endings nucleotides (A, T, G and $\mathrm{C}$ ) labelled with different fluorescent dyes, whose detection from the optical system of Illumina Genome Analyzer II gave imaging data in the form of chromatograms, subsequently processed by algorithms programs and compared to reference genomes (Genome Browsers) (107,114,118,120,123,124).

Statistical analyses. Differences in the levels of ARID1A protein and mRNA expression between cancer tissues and normal controls have been analysed by paired-samples Students' t-tests, whereas for the association between ARIDIA expression and the clinicopathological characteristics of tumours, depending on the type of findings, various methods have been applied, such as the $\chi^{2}$ test, Fisher's exact test, and non-parametric McNemar, Wilcoxon and Kruskal-Wallis techniques $(82,88,111,112,117)$. The associations between continuous variables have been evaluated by a Spearman's correlation coefficient (82). Statistically significant differences were considered data presenting a value of $\mathrm{P}<0.05(88,112,115,119)$. As regards the findings of the NGS methods, the Benjamini-Hochberg multiple test correction method was used to estimate the false discovery rate adaptive P-values $(106,120,122)$.

Survival data analyses have been performed using Kaplan-Meier survival curves, evaluated against the log-rank test, while the Cox proportional hazard model was used for the correlation between expression, survival and clinicopathological characteristics $(102,107,110,115,118,119)$. 
Table I. Loss of ARID1 A protein expression and gene mutation frequencies in histological subtypes of invasive epithelial ovarian cancers including OCCC, EnAOC, SAC, HG-SAC, LG-SAC, MAC, ASQ, ASA and OAPSMT.

\begin{tabular}{|c|c|c|c|}
\hline Author/(Refs.) & Cancer subtype & Protein loss (\%) & Mutation (\%) \\
\hline \multirow[t]{3}{*}{ Wiegand et al (9) } & $\mathrm{OCCC}$ & $55 / 132(42)$ & $55 / 119(46)$ \\
\hline & EnAOC & $39 / 125(31)$ & $10 / 33(30)$ \\
\hline & HG-SAC & 12/198 (6) & $0 / 76(0)$ \\
\hline Jones et al (8) & OCCC & N/A & $24 / 42(57)$ \\
\hline Maeda et al (128) & OCCC & $88 / 149(59)$ & $9 / 12(75)$ \\
\hline \multirow[t]{3}{*}{ Guan et al (87) } & HG-SAC & 0/221 (0) & $0 / 32(0)$ \\
\hline & LG-SAC & $0 / 15(0)$ & $0 / 19(0)$ \\
\hline & MAC & $0 / 36(0)$ & $0 / 5(0)$ \\
\hline \multirow[t]{2}{*}{ Ayhan et al (103) } & OCCC & $18 / 24(75)$ & N/A \\
\hline & EnAOC & $11 / 20(55)$ & N/A \\
\hline \multirow[t]{2}{*}{ Katagiri et al (132) } & $\mathrm{OCCC}$ & $9 / 60(15)$ & $\mathrm{N} / \mathrm{A}$ \\
\hline & HG-SAC & $0 / 17(0)$ & $\mathrm{N} / \mathrm{A}$ \\
\hline \multirow[t]{2}{*}{ Lowery et al (127) } & OCCC & $34 / 82(41)$ & $\mathrm{N} / \mathrm{A}$ \\
\hline & EnAOC & $62 / 130(48)$ & $\mathrm{N} / \mathrm{A}$ \\
\hline \multirow[t]{4}{*}{ Samartzis et al (133) } & OCCC & $5 / 23(22)$ & $\mathrm{N} / \mathrm{A}$ \\
\hline & EnAOC & $13 / 28(46)$ & $\mathrm{N} / \mathrm{A}$ \\
\hline & SAC & 7/63 (11) & $\mathrm{N} / \mathrm{A}$ \\
\hline & MAC & $4 / 15(27)$ & $\mathrm{N} / \mathrm{A}$ \\
\hline Wu et al (135) & OAPSMT & $8 / 24(33)$ & $\mathrm{N} / \mathrm{A}$ \\
\hline Xiao et al (96) & OCCC & $15 / 26(58)$ & $\mathrm{N} / \mathrm{A}$ \\
\hline Yamamoto et al (130) & OCCC & $40 / 90(44)$ & N/A \\
\hline Yamamoto et al (104) & $\mathrm{OCCC}$ & $23 / 42(55)$ & N/A \\
\hline \multirow[t]{5}{*}{ Lai et al (126) } & OCCC & $20 / 40(50)$ & N/A \\
\hline & EnAOC & $13 / 33(39)$ & $\mathrm{N} / \mathrm{A}$ \\
\hline & SAC & $2 / 4(50)$ & $\mathrm{N} / \mathrm{A}$ \\
\hline & ASQ & $1 / 1(100)$ & $\mathrm{N} / \mathrm{A}$ \\
\hline & ASA & $1 / 1(100)$ & $\mathrm{N} / \mathrm{A}$ \\
\hline Huang et al (125) & $\mathrm{OCCC}$ & $35 / 68(51)$ & $\mathrm{N} / \mathrm{A}$ \\
\hline \multirow[t]{2}{*}{ McConechy et al (134) } & LG-EnAOC & N/A & $9 / 30(30)$ \\
\hline & HG-EnAOC & $\mathrm{N} / \mathrm{A}$ & $0 / 3(0)$ \\
\hline \multirow[t]{3}{*}{ Wiegand et al (113) } & $\mathrm{OCCC}$ & $\mathrm{N} / \mathrm{A}$ & $17 / 31(55)$ \\
\hline & EnAOC & $\mathrm{N} / \mathrm{A}$ & $5 / 24(21)$ \\
\hline & SAC & $\mathrm{N} / \mathrm{A}$ & $0 / 35(0)$ \\
\hline Wu et al (129) & $\mathrm{OCCC}$ & $115 / 191(50)$ & N/A \\
\hline \multirow[t]{2}{*}{ Itamochi et al (119) } & $\mathrm{OCCC}$ & 44/112 (39) & $\mathrm{N} / \mathrm{A}$ \\
\hline & HG-SAC & 8/108 (7) & N/A \\
\hline Murakami et al (131) & OCCC & $23 / 39(56)$ & $24 / 39(62)$ \\
\hline
\end{tabular}

ARID1A, AT-rich interactive domain-containing protein 1A; OCCC, ovarian clear cell carcinoma; EnAOC, endometriosis associated ovarian carcinoma; SAC, serum adenocarcinoma; HG-SAC, high-grade serum adenocarcinoma; LG-SAC, low-grade serum adenocarcinoma; MAC, mucinous adenocarcinoma; ASQ, adenosquamous carcinoma; ASA, adenosarcoma; OAPSMT, ovarian atypical proliferating seromucinous tumours; N/A, not applicable due to the selected study method.

\section{Summary of the findings of previous studies regarding ARID1A in cancer}

Ovarian cancers. Genomic sequencing and the investigation of ARID1A immunoreactivity in the most common ovarian tumour subtype, which is ovarian clear cell carcinoma (OCCC), revealed ARID1A mutations and loss of protein expression that ranged between 46-57 and $41-62 \%$, respectively with the exception of sporadic deviations $(8,9,96,103,104,113,119,125-133)$. Mutations in the specific genomic area of interest have also been identified in 30 and $21 \%$ of endometriosis-associated ovarian cancers (EnAOCs) (9,113), while protein loss ranges between $31-55 \%(9,103,126,127,131,134)$. Zero percentages 
Table II. Loss of ARID1A protein expression and gene mutation frequencies in endometrial cancer subtypes including EEC, ESC, ECCC and ECS, and in cervical cancer subtypes including the most common CSQC and the rare CAC.

\begin{tabular}{|c|c|c|c|}
\hline Authors/(Refs.) & Cancer subtype & Protein loss $(\%)$ & Mutation (\%) \\
\hline \multirow[t]{2}{*}{ Guan et al (87) } & $\mathrm{EEC}$ & $15 / 58(26)$ & $10 / 25(40)$ \\
\hline & ESC & 0/17 (0) & N/A \\
\hline \multirow[t]{4}{*}{ Wiegand et al (143) } & EEC & $73 / 214(34)$ & $\mathrm{N} / \mathrm{A}$ \\
\hline & $\mathrm{ESC}$ & 17/95 (18) & N/A \\
\hline & $\mathrm{ECCC}$ & $6 / 23(26)$ & N/A \\
\hline & ECS & $18 / 127(14)$ & N/A \\
\hline Fadare et al (140) & $\mathrm{ECCC}$ & $5 / 22(23)$ & N/A \\
\hline \multirow[t]{2}{*}{ Katagiri et al (102) } & $\mathrm{CAC}$ & $14 / 45(31)$ & $\mathrm{N} / \mathrm{A}$ \\
\hline & CSQC & $3 / 46(6.5)$ & $\mathrm{N} / \mathrm{A}$ \\
\hline Liang et al (139) & EEC & N/A & $82 / 186(44)$ \\
\hline \multirow[t]{2}{*}{ Cho et al (101) } & $\mathrm{CAC}$ & $6 / 25(24)$ & N/A \\
\hline & CSQC & 19/116 (16) & $\mathrm{N} / \mathrm{A}$ \\
\hline Fadare et al (141) & ECCC & $10 / 50(20)$ & $\mathrm{N} / \mathrm{A}$ \\
\hline \multirow[t]{2}{*}{ Kandoth et al (138) } & EEC & N/A & $73 / 186(55)$ \\
\hline & $\mathrm{ESC}$ & N/A & 4/42 (10) \\
\hline Rahman et al (144) & EEC & $27 / 111(24)$ & N/A \\
\hline \multirow[t]{3}{*}{ Werner et al (142) } & EEC & $84 / 436(19)$ & $\mathrm{N} / \mathrm{A}$ \\
\hline & $\mathrm{ESC}$ & $1 / 44(3)$ & $\mathrm{N} / \mathrm{A}$ \\
\hline & ECCC & 4/19 (21) & $\mathrm{N} / \mathrm{A}$ \\
\hline
\end{tabular}

ARID1A, AT-rich interactive domain-containing protein 1A; EEC, endometrial endometrioid carcinoma; ESC, endometrial serous carcinoma; ECCC, endometrial clear cell carcinoma; ECS, endometrial carcinosarcoma; CSQC, cervical squamous cell carcinoma; CAC, cervical adenocarcinoma; N/A, not applicable due to the selected study method.

of mutations and expression loss have been detected in high-grade serum adenocarcinoma (HG-SAC) and low-grade serum adenocarcinoma ( $\mathrm{LG}-\mathrm{SAC})(9,87,132)$, whereas in the rare cases of adenosquamous carcinoma (ASQ), adenosarcoma (ASA) and ovarian atypical proliferative seromucinous tumours (OAPSMT), high frequencies of ARID1A mutations have been attributed to the limited number of samples $(126,135)$. As regards mucinous adenocarcinoma (MAC), two immunoreactivity studies have revealed the loss of ARID1A expression in 0 and $27 \%$ of samples respectively, while the sequence analysis detected $0 \%$ mutations $(87,131)$. The analytical findings obtained from the studies of all ovarian cancer subtypes are presented in Table I.

Four studies on the effects of the mutant gene on the prognosis of ovarian cancer found no significant differences in tumour progression, clinical status and OS between ARID1A protein-positive and -negative patients $(127,128,130,136)$. By contrast, Ayhan et al associated the loss of ARID1A expression with cancer stages I and II and Itamochi et al with a significant reduction of OS of patients at these specific cancer stages $(103,119)$. Parallel studies have reported a simultaneous overstimulation of the PI3K/AKT/mTOR signalling pathway, strong resistance to chemotherapy, reduced PFS, as well as an unaffected OS of the ARID1A protein-negative patients at III and IV cancer stages $(104,125,132,137)$.

Endometrial and cervical cancers. Three studies reported ARID1A mutation frequencies of $40-55$ and $10 \%$ in the endometrial endometrioid carcinoma (EEC) and endometrial serous carcinoma (ESC) subtypes of endometrial cancer, respectively $(87,138,139)$, whereas the loss of protein expression ranged between $20-26 \%$ in endometrial clear cell carcinoma (ECCC) $(140-143), 19-34 \%$ in $\operatorname{EEC~}(87,142-144), 0-18 \%$ in $\operatorname{ESC}(87,142,143)$ and $14 \%$ in endometrial carcinosarcoma (ECS) (143). Two immunohistochemical studies on cervical cancer subtypes demonstrated loss of ARID1A protein in 24-31 and $6.5-16 \%$ of cervical adenocarcinoma (CAC) and cervical squamous cell carcinoma (CSQC), respectively $(101,102)$. The analytical findings obtained from the studies of endometrial and cervical cancer subtypes are presented in Table II.

Two studies have reported the loss of ARID1A immunoreactivity exclusively in stages III and IV of EEC without an impact on OS or PFS survival $(140,141)$. By contrast, two parallel studies revealed reduced PFS due to resistance to chemotherapy and high metastasis of EEC ARID1A protein-negative tumours at the early stages $(102,142)$. As for the investigation of the prognostic value of the gene in the outcome of cervical cancer, only one of the two relevant studies revealed a significant reduction in the OS of ARID1A-deficient patients $(101,102)$.

Breast cancers. Studies on ARID1A mutations frequency and the loss of protein expression in unspecified breast cancer subtypes have yielded widely variable results ranging between $4-37 \%(10,90,145)$ and $1-65 \%(41,87,90,108,143,146-148)$ (Table III), while the findings of three survival analyses 
Table III. Loss of ARID1A protein expression and gene mutation frequencies in breast cancer.

\begin{tabular}{lcc}
\hline Authors/(Refs.) & Protein loss $(\%)$ & Mutation (\%) \\
\hline Guan et al $(87)$ & $1 / 91(1)$ & N/A \\
Wiegand et al $(143)$ & $11 / 315(3)$ & N/A \\
Cornen et al $(145)$ & N/A & $95 / 256(37)$ \\
Jones et al $(10)$ & N/A & $4 / 114(4)$ \\
Mamo et al $(90)$ & $151 / 236(64)$ & $11 / 82(13)$ \\
Zhang et al $(146)$ & $63 / 112(56)$ & N/A \\
Zhao et al $(147)$ & $324 / 496(65)$ & N/A \\
Cho et al $(108)$ & $150 / 476(31.5)$ & N/A \\
Takao et al $(41)$ & $63 / 127(50)$ & N/A \\
Ünçel et al $(148)$ & $123 / 92(42)$ & N/A \\
\hline
\end{tabular}

ARID1A, AT-rich interactive domain-containing protein 1A; N/A, not applicable due to the selected study method.

converged with each other, pointing out the significantly reduced OS and PFS survival of ARID1A protein-negative patients $(41,108,147)$.

The investigation of the correlation between ARID1A expression and breast cancer clinicopathologic parameters have led to different conclusions as well. Cornen et al associated the low ARID1A expression with an advanced clinical stage and high-grade invasive tumours, ER and PR negativity, HER2 positivity and poor-prognosis molecular subtypes (145). Ünçel et al confirmed that the loss of ARID1A was strongly associated with ER/PR negativity and tumour aggressiveness, but also reported that no significant association was found between ARID1A expression and molecular subtypes of breast cancer (148). Another study linked the reduced expression of ARID1A with ER/PR/HER2 triple-negative tumours, TP53 mutation and a higher Ki-67 labelling index, resulting in tumours of a larger size and higher stage (146), while the contradictory findings of Cho et al associated a low expression of ARID1A with lymph node metastasis and an advanced pathological stage, but also with a low histological grade, a low Ki-67 labelling index and a negative p53 expression, features broadly recognized as indicators of auspicious prognosis (108). Takao et al reported that the partial loss of ARID1A expression was associated with a poor prognosis and a worse PFS of patients with invasive ductal carcinoma, whilst the severe protein loss did not affect the prognosis (41). Notably, the following comprehensive gene expression analysis of cultured cancer breast cells revealed that the downregulation of ARID1A mRNA by $20 \%$ caused an increased expression of the breast cancer-promoting gene, RAB11FIP1, while the $>50 \%$ deficiency led to decreased RAB11FIP1 protein levels (41). It is worth mentioning that although $5-10 \%$ of breast cancer worldwide is attributed to pathogenic variants of the breast cancer driver genes, BRCA1/2 $(149,150)$, to date, no association has been reported between ARID1A expression and the BRCA status.

Gastric cancers. The genomic analyses of gastric cancers have reported ARID1A mutations ranging between
Table IV. Loss of ARID1A protein expression and gene mutation frequencies in gastric cancer.

\begin{tabular}{lcc}
\hline Authors/(Refs.) & Protein loss $(\%)$ & Mutation $(\%)$ \\
\hline Guan et al $(87)$ & $5 / 45(11)$ & N/A \\
Wang et al $(100)$ & $38 / 109(35)$ & $32 / 109(29)$ \\
Wiegand et al $(143)$ & $26 / 180(14)$ & N/A \\
Abe et al $(152)$ & $95 / 857(11)$ & N/A \\
Jones et al $(10)$ & N/A & $10 / 100(10)$ \\
Wang et al $(111)$ & $115 / 224(51)$ & N/A \\
Zang et al $(151)$ & N/A & $9 / 110(8)$ \\
Wiegand et al $(115)$ & $39 / 173(22.5)$ & N/A \\
2 cohorts & $16 / 80(20)$ & N/A \\
Yan et al $(46)$ & $44 / 183(24)$ & N/A \\
Ibarrola-Villava et al $(154)$ & $14 / 33(42)$ & N/A \\
Kim et al $(89)$ & $62 / 191(32.5)$ & N/A \\
Han et al $(153)$ & $88 / 417(21)$ & N/A \\
Kim et al $(155)$ & $52 / 350(15)$ & N/A \\
Aso et al $(69)$ & $103 / 516(20)$ & N/A
\end{tabular}

ARID1A, AT-rich interactive domain-containing protein 1A; N/A, not applicable due to the selected study method.

$8-29 \%(10,100,151)$, while the loss of protein expression has been found in $11-51 \%$ of tumours, often associated with MSI and Epstein-Barr infection $(46,69,87,89,100,111,115,143,15$ 2-155) (Table IV). Two studies have reported that the loss of expression of ARID1A was unrelated to gastric cancer clinical characteristics $(115,154)$. On the contrary, Yan et al associated the reduced ARID1A expression with CDH1 silencing and subsequent decreased E-cadherin levels that enhance gastric cancer migration and invasion, leading to local lymph node metastasis and tumour infiltration (46). Another study associated the loss of ARID1A expression with higher $\mathrm{T}$ stage infiltration, but not with distant or lymph node metastasis (111), while the findings of Kim et al associated the loss of ARID1A with poorly differentiated subtypes located in the upper third of the stomach, showing frequent vascular invasion (89).

The strong positive association of ARID1A deficiency with EBV positivity, high MSI and the loss of mismatch repair (MMR) protein expression has been consistently repor ted $(69,89,100,115,151-153)$. In particular, Wang et al detected inactivating ARID1A mutations and protein loss in $83 \%$ of gastric cancers with MSI and in $73 \%$ of those carrying EBV infection (100), while two studies reported that ARID1A deficiency was significantly more frequent in EBV-positive and MLH1-negative gastric carcinomas, suggesting that the EBV-associated promoter hypermethylation downregulates the expression of both genome guardians $(69,152)$. Of note, among the two MMR genes, Kim et al confirmed a positive correlation between ARID1A and MLH1 decreased levels in gastric tumours, but found no association with MLH2 expression (89). Zang et al detected ARID1A mutations in $8 \%$ of tumours characterised by concurrent MSI and PIK3CA mutations (151), while no significant association 
Table V. Loss of ARID1A protein expression and gene mutation frequencies in liver, pancreatic, gallbladder, intestinal, oesophageal, thyroid and lung cancers.

\begin{tabular}{|c|c|c|c|}
\hline Cancer type & Authors/(Refs.) & Protein loss $(\%)$ & Mutation (\%) \\
\hline \multirow[t]{4}{*}{ Liver } & Guan et al (87) & $0 / 41(0)$ & $\mathrm{N} / \mathrm{A}$ \\
\hline & Fujimoto et al (157) & N/A & $15 / 147(10)$ \\
\hline & Guichard et al (158) & $20 / 125(16)$ & 20/125 (16) \\
\hline & He et al (88) & 41/64 (64) & N/A \\
\hline \multirow[t]{4}{*}{ Pancreas } & Guan et al (87) & $4 / 48(8)$ & $\mathrm{N} / \mathrm{A}$ \\
\hline & Wiegand et al (143) & $5 / 85(6)$ & N/A \\
\hline & Jones et al (10) & N/A & $10 / 119(8)$ \\
\hline & Zhang et al (116) & $10 / 73(7)$ & N/A \\
\hline \multirow[t]{3}{*}{ Gallbladder } & Guan et al (87) & 2/27 (7) & N/A \\
\hline & Jiao et al (121) & N/A & $9 / 64(14)$ \\
\hline & Ahn et al (106) & N/A & 25/183 (14) \\
\hline \multirow[t]{7}{*}{ Colorectal } & Guan et al (87) & $2 / 49(4)$ & $\mathrm{N} / \mathrm{A}$ \\
\hline & Wiegand et al (143) & $2 / 250(1)$ & $\mathrm{N} / \mathrm{A}$ \\
\hline & Jones et al (10) & N/A & $12 / 119(10)$ \\
\hline & Cajuso et al (114) & N/A & 18/46 (39) \\
\hline & Wei et al (112) & $54 / 209(25.8)$ & N/A \\
\hline & Sen et al (161) & 24/164 (14.6) & N/A \\
\hline & Lee et al (160) & $12 / 196(6)$ & $\mathrm{N} / \mathrm{A}$ \\
\hline Ampulla of vater & Nastase et al (118) & N/A & $4 / 49(8.2)$ \\
\hline Duodenum & Nastase et al (118) & $\mathrm{N} / \mathrm{A}$ & $2 / 6(33)$ \\
\hline \multirow[t]{2}{*}{ Oesophagus } & Streppel et al (159) & $12 / 98(12)$ & $3 / 20(15)$ \\
\hline & Drage et al (109) & $12 / 120(10)$ & N/A \\
\hline Thyroid & Wiegand et al (143) & 5/35 (14) & N/A \\
\hline Lung & Imielinski et al (156) & N/A & 15/183 (8) \\
\hline
\end{tabular}

ARID1A, AT-rich interactive domain-containing protein 1A; N/A, not applicable due to the selected study method.

Table VI. Loss of ARID1A protein expression and gene mutation frequencies in bladder, renal and prostate cancers.

\begin{tabular}{llcr}
\hline Cancer type & \multicolumn{1}{c}{ Authors/(Refs.) } & Protein loss $(\%)$ & Mutation $(\%)$ \\
\hline Bladder & Gui et al $(120)$ & N/A & $13 / 97(13)$ \\
& Balbás-Martínez et al $(107)$ & N/A & 6/52 (12) \\
& Guo et al $(162)$ & N/A & 15/99 (15) \\
& Faraj et al $(110)$ & $16 / 122(13)$ & N/A \\
Renal & Guan et al $(87)$ & $0 / 73(0)$ & N/A \\
& Wiegand et al $(143)$ & $1 / 58(2)$ & N/A \\
& Lichner et al $(82)$ & $53 / 79(67)$ & N/A \\
\hline
\end{tabular}

ARID1A, AT-rich interactive domain-containing protein 1A; N/A, not applicable due to the selected study method.

was reported between the loss of ARID1A expression and HER2 amplification (115). The negative association between ARID1A and TP53 mutations has been reported in four studies, highlighting the mutual exclusivity of the two tumour suppressors $(69,100,115,153)$.

Two studies associated the decreased expression of ARID1A and genetic alterations with a significantly improved
OS and prognosis $(100,154)$, contrary to the findings of five studies that reported a high tumour differentiation and a significantly reduced PFS of ARID1A protein-negative patients $(46,111,152,153,155)$.

Liver, pancreatic, gallbladder, intestinal, oesophageal, thyroid and lung cancers. Table $\mathrm{V}$ lists the results of genomic 
Table VII. Loss of ARID1A protein expression and gene mutation frequencies in nervous (myeloblastoma, neuroblastoma, glioma) and lymphatic (macroglobulinemia Waldenström, Burkitt lymphoma) system cancers.

\begin{tabular}{llcc}
\hline Cancer type & \multicolumn{1}{c}{ Authors/(Refs.) } & Protein loss (\%) & Mutation (\%) \\
\hline Myeloblastoma & Jones et al $(10)$ & N/A & $3 / 125(2)$ \\
Neuroblastoma & Sausen et al $(122)$ & N/A & $4 / 71(6)$ \\
Glioma & Tan et al $(117)$ & $62 / 83(75)$ & N/A \\
Macroglobulinemia Waldenström & Treon et al $(163)$ & N/A & $5 / 30(17)$ \\
Burkitt lymphoma & Giulino-Roth et al $(164)$ & N/A & $5 / 29(17)$ \\
\hline
\end{tabular}

ARID1A, AT-rich interactive domain-containing protein 1A; N/A, not applicable due to the selected study method.

and immunohistochemical analyses of liver, pancreatic, gallbladder, intestinal, oesophageal, thyroid and lung cancer tissues. Among all, the highest frequency of ARID1A mutations of $39 \%$ was found in colorectal tumours (114) and the lowest of $8 \%$ in cancers of the pancreas, the duodenum and the lung $(10,118,156)$. Although protein loss was detected mostly at a low rate $0-16 \%$ of malignancies $(87,109,116,143,157-161)$, two studies reported the loss of ARID1A immunoreactivity in 64\% of liver tumours (88) and in $25.8 \%$ of colorectal cancers (112).

As regards colorectal cancer, Wei et al reported that the loss of ARID1A expression was significantly associated with a late TNM stage, distant metastasis and poor pathological differentiation, but did not seem to affect the tumour T stage, size or location (112), in partial accordance with the findings of Lee et al that associated the loss of ARID1A expression with expanding tumour borders, but negative lymphatic invasion (160). In parallel, two studies reported the positive association between ARID1A mutations and MSI colorectal cancers $(10,114)$, while Cajuso et al, based on a limited number of study samples, questioned the relevance of mutual exclusiveness between ARID1A and TP53 mutations in colorectal cancer (114). Of note, the molecular analyses of two KRAS wild-type and two KRAS ${ }^{\mathrm{G} 13 \mathrm{D}}$ colorectal cancer cell lines, subjected to CRISPR/Cas9-mediated ARID1A deletion, led Sen $e t$ al to the conclusion that KRAS mutated colorectal cancer cells are particularly dependent on ARID1A presence, as their proliferation proved to be severely impaired by its absence, due to the decreased activity of specific enhancers bound by ARID1A and the AP1 transcription factors, that subsequently caused the down regulation of 48 genes (161).

Survival analyses have not detected a statistically significant difference in OS between ARID1A protein-positive and -negative patients with oesophageal, pancreatic and colorectal cancers $(109,112,116)$. On the contrary, in the case of hepatocellular carcinoma, the loss of expression has been shown to be associated with a poor prognosis and high metastaticity of the tumour (88), whereas in the case of cancer of the ampulla of Vater, it was found that the mutation of the gene is associated with an increased overall survival (118).

Bladder, renal and prostate cancers. Three sequencing analyses of bladder cancer genomes have revealed a mean ARID1A mutation frequency of $13.5 \%(107,120,162)$, while IHC analyses have detected the loss of protein expression in 0,2 and $67 \%$ of renal malignancies $(82,87,143)$, in $13 \%$ of bladder tumours (110) and in $8 \%$ of prostate cancers (10) (Table VI). Two survival studies have found that ARID1A mutation is associated with the reduced OS and PFS of bladder and kidney cancer patients $(82,107)$, while Faraj et al reported that ARID1A protein loss was associated with the first stage of bladder cancer and positively affected prognosis (110).

Nervous and lymphatic system cancers. ARID1A mutations detected in myeloblastoma, neuroblastoma, Burkitt lymphoma and Waldenström macroglobulinemia genomes ranged between $2-17 \%(10,122,163,164)$, while the loss of protein expression was found in $75 \%$ of the glioma serum samples (117) (Table VII). The parallel investigation of the effect of the inactivated gene on the prognosis of patients with neuroblastoma and glioma revealed a significant reduction in the OS of ARID1A protein-negative patients $(117,122)$.

\section{Discussion}

The dynamic remodeling of chromatin is a key mechanism for proper cellular function, as it enables the transcription, replication and repair of genetic material, regulates gene expression, while at the same time prevents chromosome breakage and supports the exact DNA distribution during cell divisions, thus ensuring the preservation of the cellular phenotype across generations (165). In order to respond to environmental stimuli and developmental signals that require the activation or suppression of particular genes, chromatin's structure is appropriately remodeled by the SWI/SNF protein complexes, which bind to the onset loci of the upcoming transcriptional activity under the guidance of the ARID1A subunit and rearrange the array of nucleosomes along the double stranded helix length $(32,37)$. The mutation of the ARID1A gene diverts the remodeling mechanism and besides its epigenetic implications, results involved in carcinogenesis in many other ways that have not been fully elucidated yet (4).

Laboratory studies investigating the frequency of ARID1A mutations and the loss of homologous protein expression have been conducted worldwide over the past decade and have spread to almost the entire spectrum of human cancers. Most of these have focused on the association between oncogenesis and gene inactivation in gynaecological and gastrointestinal cancers, revealing a substantive association, while concrete-positive indications have been reported by the majority of malignant neoplasms studies consolidating its 
tumour-suppressive role. However, the contemporary scientific community has not precisely defined yet the diagnostic significance and the clinical implications of the mutant ARID1A, as the findings of genomic and immunohistochemical analyses show a high degree of heterogeneity among the various cancer tissues, whereas wide ranges of variations are observed even between cancers of the same type and subtype (13).

Highest mutation frequencies, often $>50 \%$, have been recorded in ovarian, endometrial and breast cancer tissues, attributable to the hormone-dependent nature of these specific malignancies and the interactions of the gene with nuclear hormone receptors during transcriptional regulation (12). Mutation frequencies ranging between $8-39 \%$ have been detected in gastrointestinal cancers $(10,100,114,118,151)$, while $<10 \%$ rates have been detected in lung, prostate, pancreatic and intracranial tumours $(10,122,156)$. The findings of three immunohistochemistry-based studies of the same ovarian tumour subtype OCCC, reporting the loss of ARID1A expression in 75, 22 and $15 \%$ of the samples $(103,131,132)$, are indicative of the wide heterogeneity between the results of various studies, although the reliability of the IHC method is unquestionable. In fact, a study based on the concurrent comparative analyses of ARID1A mutational status and immunoreactivity reported the concordance of results in $91 \%$ of the OCCC ovarian cancers examined, demonstrating $100 \%$ sensitivity and 66\% specificity of the IHC method (128).

The findings of the relatively limited number of survival analyses conducted to investigate the prognostic value of the ARID1A gene in the outcome of cancer treatment appear to be controversial as well. Actually, relevant studies have reported adverse, beneficial or absolutely no effect of protein loss on the biological behaviour and metastaticity of tumours, the outcome of chemotherapy, the recurrence of cancer, the PFS and the OS of cancer patients, thus clarifying that the abnormal expression of ARID1A affects the prognosis in different ways, mainly depending on the type, stage and grade of the tumour $(107,110,117,136)$.

Among the factors that have been found to influence the prognosis of specific malignancies, the existence of concomitant PIK3CA, TP53, EZH2 and KRAS mutations has been proven to be of great significance and has led to the deterioration of ARID1A-deficient gynaecological cancers, while in gastric malignancies the synergy of ARID1A protein loss with the expression of E-cadherin, MSI and the simultaneous presence of Epstein-Barr virus was detected in highly aggressive tumours $(46,89,100,152,153)$. In addition to the clinicopathological characteristics of the tumours, the heterogeneity of the research findings is attributed to other factors as well, such as the occasionally limited number of samples, the use of different antibodies in the immunoassays conducted, the general characteristics, the clinical condition and the racial origin of the patients $(12,81)$.

\section{Conclusion and future therapeutic perspectives}

The enlightenment of the diagnostic significance and the prognostic role of the ARID1A gene in cancer entails the exclusion of the specific parameters, which embroil the research findings, hence requires new highly specialized research approaches to tumours and patients with common clinicopathological and anthropological characteristics (11). The identification of the association between the mutational status of the gene, the stages and the grading of malignant tumours can lead on the one hand to the development of an early diagnosis methodology and on the other hand to the identification and distinction between low and high risk patients in order to be subjected to a more personalized and targeted therapeutic intervention, thus avoiding the effects of over-treatment $(11,12,113)$.

Undoubtedly, the full decoding of the ARID1A tumour suppressor mechanism and the development of targeted gene therapy are part of the future field of investigation. Moreover, in exploiting the proven interaction of the gene with the $\mathrm{PI} 3 \mathrm{~K} / \mathrm{AKT} / \mathrm{mTOR}$ intracellular signalling pathway, whose diversion disrupts cell proliferation and leads to carcinogenesis, contemporary experimental studies have attempted to develop novel chemotherapeutic regimens for the treatment of ARID1A protein-negative tumours, including inhibitors of the kinases PI3K and AKT, among which buparlisib and the combination of MK-2206/perifosine were the most effective $(92,93)$, in contrast to cytostatic cisplatin which proved to be ineffective in suppressing ARID1A negative, ovarian cancer cell lines (14).

Parallel therapeutic approaches are currently focused on the epigenetic aberrations and the deficient DNA damage responses caused by the loss of ARID1A expression, aiming to identify a potential ARID1A-synthetic lethality target. Recently, Bitler et al reported that the pharmacological inhibition of the histone deacetylase 6 (HDAC6) in mouse models of ARID1A-mutated ovarian tumours suspended the tumour expansion and improved the survival of the treated mice (166), while another study reported the synthetic lethality between EZH2 methyltransferase inhibition and ARID1A-mutated ovarian cancer cell lines (167). According to the in vitro and in vivo findings of Shen et al, PARP inhibitors, already known to be selectively lethal to cells carrying BRCA1 or BRCA2 mutations, two proteins involved in the DNA damage signalling pathway similarly to ARID1A, represent a potential therapeutic strategy for ARID1A mutant tumours as well (60).

\section{Acknowledgements}

Not applicable.

\section{Funding}

No funding was received.

\section{Availability of data and materials}

Not applicable.

\section{Authors' contributions}

VB conceived and ENP designed this review article. ENP and VB collected and evaluated the research articles included in this review. VB supervised the project. ENP wrote the manuscript and designed the figure. VB revised the manuscript critically for important intellectual content. All authors agreed to be accountable for all aspects of the work in ensuring that questions related to the accuracy or integrity of any part of the work are appropriately investigated and resolved. All authors have read and approved the final manuscript. 


\section{Ethics approval and consent to participate}

Not applicable.

\section{Patient consent for publication}

Not applicable.

\section{Competing interests}

The authors declare that they have no competing interests.

\section{References}

1. Bagchi A and Mills AA: The quest for the 1p36 tumor suppressor. Cancer Res 68: 2551-2556, 2008.

2. Reisman D, Glaros S and Thompson EA: The SWI/SNF complex and cancer. Oncogene 28: 1653-1668, 2009.

3. Wu JN and Roberts CW: ARID1A mutations in cancer: Another epigenetic tumor suppressor? Cancer Discov 3: 35-43, 2013.

4. Guan B, Gao M, Wu CH, Wang TL and Shih IM: Functional analysis of in-frame indel ARID1A mutations reveals new regulatory mechanisms of its tumor suppressor functions Neoplasia 14: 986-993, 2012

5. Samartzis EP, Noske A, Dedes KJ, Fink D and Imesch P: ARID1A mutations and PI3K/AKT pathway alterations in endometriosis and endometriosis-associated ovarian carcinomas. Int J Mol Sci 14: 18824-18849, 2013

6. Wang X, Nagl NG Jr, Flowers S, Zweitzig D, Dallas PB and Moran E: Expression of p270 (ARID1A), a component of human SWI/SNF complexes, in human tumors. Int J Cancer 112: 636 , 2004.

7. Flores-Alcantar A, Gonzales-Sandoval A, Escalante-Alcalde D and Lomeli H: Dynamics of expression of ARID1A and ARID1B subunits in mouse embryos and in cells during the cell cycle. Cell Tissue Res 345: 137-148, 2011.

8. Jones S, Wang TL, Shih IeM, Mao TL, Nakayama K, Roden R, Glas R, Slamon D, Diaz LA Jr, Vogelstein B, et al: Frequent mutations of chromatin remodeling gene ARID1A in ovarian clear cell carcinoma. Science 330: 228-231, 2010.

9. Wiegand KC, Shah SP, Al-Agha OM, Zhao Y, Tse K, Zeng T, Senz J, McConechy MK, Anglesio MS, Kalloger SE, et al ARID1A mutations in endometriosis-associated ovarian carcinomas. N Engl J Med 363: 1532-1543, 2010.

10. Jones S, Meng L, Parsons DW, Zhang X, Wesseling J, Kristel P, Schmidt MK, Markowitz S, Yan H, Bigner D, et al: Somatic mutations in the chromatin remodeling gene ARID1A occur in several tumor types. Hum Mutat 33: 100-103, 2012.

11. Luchini C, Veronese N, Solmi M, Cho H, Kim JH, Chou A, Gill AJ, Faraj SF, Chaux A, Netto GJ, et al: Prognostic role and implications of mutation status of tumor suppressor gene ARID1A in cancer: A systematic review and meta-analysis. Oncotarget 6: 39088-39097, 2015.

12. Mao TL and Shih IeM: The roles of ARID1A in gynecologic cancer. J Gynecol Oncol 24: 376-381, 2013.

13. Wu RC, Wang TL and Shih IeM: The emerging roles of ARID1A in tumor suppression. Cancer Biol Ther 15: 655-664, 2014.

14. Lyu C, Zhang Y, Zhou X and Lang J: ARID1A gene silencing reduces the sensitivity of ovarian clear cell carcinoma to cisplastin. Exp Ther Med 12: 4067-4071, 2016.

15. Gregory SL, Kortschak DR, Kallionis B and Saint R: Characterization of the dead ringer gene identifies a novel, highly conserved family of sequence-specific DNA-binding proteins. Mol Cell Biol 16: 792-799, 1996.

16. Herrscher RF, Kaplan MH, Lelsz DL, Das C, Scheuermann R and Tucker PW: The immunoglobulin heavy-chain matrix-associating regions are bound by Bright: A B cell-specific trans-activator that describes a new DNA-binding protein family. Genes Dev 9: 3067-3082, 1995.

17. Patsialou A, Wilsker D and Moran E: DNA-binding properties of ARID family proteins. Nucleic Acids Res 33: 66-80, 2005.

18. Dallas PB, Pacchione S, Wilsker D, Bowrin V, Kobayashi R and Moran E: The human SWI-SNF complex protein p270 is an ARID family member with non-sequence-specific DNA binding activity. Mol Cell Biol 20: 3137-3146, 2000.
19. Wang X, Haswell JR and Roberts CW: Molecular pathways: SWI/SNF (BAF) complexes are frequently mutated in cancer-mechanisms and potential therapeutic insights. Clin Cancer Res 20: 21-27, 2014

20. Carlson M, Osmond BC and Botstein D: Mutants of yeast defective in sucrose utilization. Genetics 98: 25-40, 1981.

21. Wilsker D, Patsialou A, Zumbrun SD, Kim S, Chen Y, Dallas PB and Moran E: The DNA-binding properties of the ARID-containing subunits of yeast and mammalian SWI/SNF complexes. Nucleic Acids Res 32: 1345-1353, 2004.

22. Kwon H, Imbalzano AN, Khavari PA, Kingston RE and Green MR: Nucleosome disruption and enhancement of activator binding by a human SWI/SNF complex. Nature 370: 477-481, 1994.

23. Li XS, Trojer P, Matsumura T, Treisman JE and Tanese N: Mammalian SWI/SNF-a subunit BAF250/ARID1 is an E3 ubiquitin ligase that targets histone H2B. Mol Cell Biol 30: $1673-1688,2010$

24. Narlicar GJ, Sundaramoorthy $\mathrm{R}$ and Owen-Hughes T: Mechanisms and functions of ATP-dependent chromatin-remodeling enzymes. Cell 154: 490-503, 2013.

25. Smith CL and Peterson CL: A conserved Swi2/Snf2 ATPase motif couples ATP hydrolysis to chromatin remodeling. Mol Cell Biol 25: 5880-5892, 2005

26. Becker PB: Nucleosome sliding: Facts and fiction. EMBO J 21: 4749-4753, 2002

27. Cairns BR: Chromatin remodeling: Insights and intrigue from single-molecule studies. Nat Struct Mol Biol 14: 989-996, 2007.

28. Hargreaves DC and Crabtree GR: ATP-dependent chromatin remodeling: Genetics, genomics and mechanisms. Cell Res 21: 396-420, 2011

29. Vignali M, Hassan AH, Neely KE and Workman JL: ATP-dependent chromatin-remodeling complexes. Mol Cell Biol 20: 1899-1910, 2000.

30. Schnitzler G, Sif S and Kingston RE: Human SWI/SNF interconverts a nucleosome between its base state and a stable remodeled state. Cell 94: 17-27, 1998.

31. Imbalzano AN, Kwon H, Green MR and Kingston RE: Facilitated binding of TATA-binding protein to nucleosomal DNA. Nature 370: 481-485, 1994.

32. Bartolomew B: Regulating the chromatin landscape: Structural and mechanistic perspectives. Annu Rev Biochem 83: 671-696, 2014.

33. Jeong KW, Lee $\mathrm{YH}$ and Stallcup MR: Recruitment of the SWI/SNF chromatin remodeling complex to steroid hormone-regulated promoters by nuclear receptor coactivator flightless-I. J Biol Chem 284: 29298-29309, 2009.

34. Ronan JL, Wu W and Crabtree GR: From neural development to cognition: Unexpected roles for chromatin. Nat Rev Genet 14: 347-359, 2013.

35. Decristofaro MF, Betz BL, Rorie CJ, Reisman DN, Wang W and Weissman BE: Characterization of SWI/SNF protein expression in human breast cancer cell lines and other malignancies. J Cell Physiol 186: 136-145, 2001.

36. Inoue H, Furukawa T, Giannakopoulos S, Zhou S, King DS and Tanese N: Largest subunits of the human SWI/SNF chromatin-remodeling complex promote transcriptional activation by steroid hormone receptors. J Biol Chem 277: 41674-41685, 2002.

37. Kadoch C, Hargreaves DC, Hodges C, Elias L, Ho L, Ranish J and Crabtree GR: Proteomic and bioinformatic analysis of mammalian SWI/SNF complexes identifies extensive roles in human malignancy. Nat Genet 45: 592-601, 2013.

38. Keenen B, Qi H, Saladi SV, Yeung M and de la Serna IL: Heterogeneous SWI/SNF chromatin remodeling complexes promote expression of microphthalmia-associated transcription factor target genes in melanoma. Oncogene 29: 81-92, 2010.

39. Tang L, Nogales E, Ciferri C: Structure and function of SWI/SNF chromatin remodeling complexes and mechanistic implications for transcription. Prog Biophys Mol Biol 102: 122-128, 2010.

40. Nie Z, Xue Y, Yang D, Zhou S, Deroo BJ, Archer TK and Wang W: A specificity and targeting subunit of a human SWI/SNF family-related chromatin-remodeling complex. Mol Cell Biol 20: 8879-8888, 2000.

41. Takao C, Morikawa A, Ohkubo H, Kito Y, Saigo K, Sakuratami T, Futamura M, Takeuchi T and Yoshida K: Downregulation of ARID1A, a component of the SWI/SNF chromatin remodeling complex, in breast cancer. J Cancer 8: 1-8, 2017.

42. Inoue $\mathrm{H}$, Giannakopoulos $\mathrm{S}$, Parkhurst $\mathrm{CN}$, Matsumura $\mathrm{T}$, Kono EA, Furukawa T and Tanese N: Target genes of the largest human SWI/SNF complex subunit control cell growth. Biochem J 434: 83-92, 2011. 
43. Dechassa ML, Zhang B, Horowitz-Scherer R, Persinger J, Woodcock CL, Peterson CL and Bartholomew B: Architecture of the SWI/SNF-nucleosome complex. Mol Cell Biol 28 : 6010-6021, 2008.

44. Nagl NG Jr, Wang X, Patsialou A, Van Scoy M and Moran E: Distinct mammalian SWI/SNF chromatin remodeling complexes with opposing roles in cell-cycle control. EMBO J 26: 752-763, 2007.

45. Wang X, Nagl NG, Wilsker D, Van Scoy M, Pacchione S, Yaciuk P, Dallas PB and Moran E: Two related ARID family proteins are alternative subunits of human SWI/SNF complexes. Biochem J 383: 319-325, 2004.

46. Yan HB, Wang XF, Zhang Q, Tang ZQ, Jiang YH, Fan HZ, Sun Y, Yang PY and Liu F: Reduced expression of the chromatin remodeling gene ARID1A enhances gastric cancer cell migration and invasion via downregulation of E-cadherin transcription. Carcinogenesis 35: 867-876, 2014

47. Saghafinia S, Mina M, Riggi N, Hanahan D and Ciriello G: Pan-cancer landscape of aberrant DNA methylation across human tumors. Cell Rep 25: 1066-1080.e8, 2018.

48. Kamińska K, Nalejska E, Kubiak M, Wojtysiak J, Żołna Ł, Kowalewski J and Lewandowska MA: Prognostic and predictive epigenetic biomarkers in oncology. Mol Diagn Ther 23: 83-95, 2019.

49. Tsai HC and Baylin SB: Cancer epigenetics: Linking basic biology to clinical medicine. Cell Res 21: 502-517, 2011.

50. Heinz S, Romanoski CE, Benner C and Glass CK: The selection and function of cell type-specific enhancers. Nat Rev Mol Cell Biol 16: 144-154, 2015.

51. Tillo D, Kaplan N, Moore IK, Fondufe-Mittendorf Y, Gossett AJ, Field Y, Lieb JD, Widom J, Segal E and Hughes TR: High nucleosome occupancy is encoded at human regulatory sequences PLoS One 5: e9129, 2010.

52. Sun X, Chuang JC, Kanchwala M, Wu L, Celen C, Li L, Liang H, Zhang S, Maples T, Nguyen LH, et al: Suppression of the SWI/SNF component Arid1a promotes mammalian regeneration. Cell Stem Cell 18: 456-466, 2016.

53. Wu S, Zhang R and Bitler BG: Arid1a controls tissue regeneration. Stem Cell Investig 3: 35, 2016.

54. Lei I, West J, Yan Z, Gao X, Fang P, Dennis JH, Gnatovskiy L, Wang W, Kingston RE and Wang Z: BAF250a protein regulates nucleosome occupancy and histone modifications in priming embryonic stem cell differentiation. J Biol Chem 290 19343-19352, 2015.

55. Gao X, Tate P, Hu P, Tjian R, Skarnes WC and Wang Z: ES cell pluripotency and germ-layer formation require the SWI/SNF chromatin remodeling component BAF250a. Proc Natl Acad Sc USA 105: 6656-6661,2008.

56. Han L, Madan V, Mayakonda A, Dakle P, Woon TW, Shyamsunder P, Nordin HBM, Cao Z, Sundaresan J, Lei I, et al: Chromatin remodeling mediated by ARID1A is indispensable for normal hematopoiesis in mice. Leukemia 33: 2291-2305, 2019.

57. Hota SK, Johnson JR, Verschueren E, Thomas R, Blotnick AM, Zhu Y, Sun X, Pennacchio LA, Krogan NJ and Bruneau BG: Dynamic BAF chromatin remodeling complex subunit inclusion promotes temporally distinct gene expression programs in cardiogenesis. Development 146: pii: dev174086, 2019.

58. Lei I, Gao X, Sham MH and Wang Z: SWI/SNF protein component BAF250a regulates cardiac progenitor cell differentiation by modulating chromatin accessibility during second heart field development. J Biol Chem 287: 24255-24262, 2012.

59. Watanabe R, Ui A, Kanno S, Ogiwara H, Nagase T, Kohno T and Yasui A: SWI/SNF factors required for cellular resistance to DNA damage include ARID1A and ARID1B and show interdependent protein stability. Cancer Res 74: 2465-2475, 2014.

60. Shen J, Peng Y, Wei L, Zhang W, Yang L, Lan L, Kapoor P, Ju Z, Mo Q, Shih IM, et al: ARID1A deficiency impairs the DNA damage checkpoint and sensitizes cells to PARP inhibitors. Cancer Discov 5: 752-767, 2015.

61. Lakshminarasimhan R, Andreu-Vieyra C, Lawrenson K, Duymich CE, GaytherSA,Liang G and Jones PA: Down-regulation of ARID1A is sufficient to initiate neoplastic transformation along with epigenetic reprogramming in non-tumorigenic endometriotic cells. Cancer Lett 401: 11-19, 2017.

62. Miranda TB and Jones PA: DNA methylation: The nuts and bolts of repression. J Cell Physiol 213: 384-390, 2007.

63. Jang HS, Shin WJ, Lee JE and Do JT: CpG and Non-CpG methylation in epigenetic gene regulation and brain function. Genes (Basel) 8: pii: E148, 2017.
64. Herman JG, Latif F, Weng Y, Lerman MI, Zbar B, Liu S, Samid D, Duan DS, Gnarra JR, Linehan WM, et al: Silencing of the VHL tumor-suppressor gene by DNA methylation in renal carcinoma. Proc Natl Acad Sci USA 91: 9700-9704, 1994.

65. Baylin SB, Makos M, Wu JJ, Yen RW, De Bustros A, Vertino P and Nelkin BD: Abnormal patterns of DNA methylation in human neoplasia: Potential consequences for tumor progression. Cancer Cells 3: 383-390, 1991.

66. Makos M, Nelkin BD, Lerman MI, Latif F, Zbar B and Baylin SB: Distinct hypermethylation patterns occur at altered chromosome loci in human lung and colon cancer. Proc Natl Acad Sci USA 89; 1929-1933, 1992.

67. Qu Y, Dang S and Hou P: Gene methylation in gastric cancer. Clin Chim Acta 424: 53-65, 2013.

68. Zhang X, Sun Q, Shan M, Niu M, Liu T, Xia B, Liang X, Wei W, Sun S, Zhang Y, et al: Promoter hypermethylation of ARID1A gene is responsible for its low mRNA expression in many invasive breast cancers. PLoS One 8: e53931, 2013.

69. Aso T, Uozaki H, Morita S, Kumagai A and Watanabe M: Loss of ARID1A, ARID1B, and ARID2 expression during progression of gastric cancer. Anticancer Res 35: 6819-6827, 2015.

70. Xie H, Chen P, Huang HW, Liu LP and Zhao F: Reactive oxygen species downregulate ARID1A expression via its promoter methylation during the pathogenesis of endometriosis. Eur Rev Med Pharmacol Sci 21: 4509-4515, 2017.

71. Ibragimova I, Maradeo ME, Dulaimi E and Cairns P: Aberrant promoter hypermethylation of PBRM1, BAP1, SETD2, KDM6A and other chromatin-modifying genes is absent or rare in clear cell RCC. Epigenetics 8: 486-493, 2013.

72. Xiao W, Lou N, Ruan H, Bao L, Xiong Z, Yuan C, Tong J, Xu G, Zhou Y, Qu Y, et al: Mir-144-3p promotes cell proliferation, metastasis, sunitinib resistance in clear cell renal cell carcinoma by downregulating ARID1A. Cell Physiol Biochem 43: 2420-2433, 2017

73. Lee RC, Feinbaum RL and Ambros V: The C. elegans heterochronic gene lin-4 encodes small RNAs with antisense complementarity to lin-14. Cell 75: 843-854, 1993.

74. He L and Hannon GJ: MicroRNAs: Small RNAs with a big role in gene regulation. Nat Rev Genet 5: 522-531, 2004.

75. Iorio MV and Croce CM: MicroRNAs in cancer: Small molecules with a huge impact. J Clin Oncol 27: 5848-5856, 2009.

76. Yang F, Xu Y, Liu C, Ma C, Zou S, Xu X, Jia J and Liu Z: NF- $\kappa \mathrm{B} / \mathrm{miR}-223-3 \mathrm{p} / \mathrm{ARID} 1 \mathrm{~A}$ axis is involved in Helicobacter pylori CagA-induced gastric carcinogenesis and progression. Cell Death Dis 9: 12, 2018

77. Lu WC, Liu CJ, Tu HF, Chung YT, Yang CC, Kao SY, Chang KW and Lin SC: miR-31 targets ARID1A and enhances the oncogenicity and stemness of head and neck squamous cell carcinoma. Oncotarget 7: 57254-57267, 2016.

78. Wang N, Zhou Y, Zheng L and Li H: MiR-31 is an independent prognostic factor and functions as an oncomir in cervical cancer via targeting ARID1A. Gynecol Oncol 134: 129-137, 2014.

79. Yang Y, Zhao X and Li HX: MiR-221 and miR-222 simultaneously target ARID1A and enhance proliferation and invasion of cervical cancer cells. Eur Rev Med Pharmacol Sci 20: 1509-1515, 2016.

80. Li ZY, Zhu SS, Chen XJ, Zhu J, Chen Q, Zhang YQ, Zhang CL, Guo TT and Zhang LM: ARID1A suppresses malignant transformation of human pancreatic cells via mediating senescence-associated miR-503/CDKN2A regulatory axis. Biochem Biophys Res Commun 493: 1018-1025, 2017.

81. Kim YS, Jeong H, Choi JW, Oh HE and Lee JH: Unique characteristics of ARID1A mutation and protein level in gastric and colorectal cancer: A meta-analysis. Saudi J Gastroenterol 23: 268-274, 2017.

82. Lichner Z, Scorilas A, White NM, Girgis AH, Rotstein L, Wiegand KC, Latif A, Chow C, Huntsman D and Yousef GM: The chromatin remodeling gene ARID1A is a new prognostic marker in clear cell carcinoma. Am J Pathol 182: 1163-1170, 2013.

83. Takeda T, Banno K, Okawa R, Yanokura M, Iijima M, Irie-Kunitomi $H$, Nakamura $K$, Iida $M$, Adachi $M$, Umene K, et al: ARID1A gene mutation in ovarian and endometrial cancers (Review). Oncol Rep 35: 607-613, 2016.

84. Dawson MA and Kouzarides T: Cancer epigenetics: From mechanism to therapy. Cell 150: 12-27, 2012.

85. Okawa R, Banno K, Iida M, Yanokura M, Takeda T, Iijima M, Kunitomi-Irie H, Nakamura K, Adachi M, Umene K, et al: Aberrant chromatin remodeling in gynecological cancer. Oncol Lett 14: 5107-5113, 2017 
86. Wang Y, Wysocka J, Perlin JR, Leonelli L, Allis CD and Coonrod SA: Linking covalent histone modifications to epigenetics: The rigidity and plasticity of the marks. Cold Spring Harb Symp Quant Biol 69: 161-169, 2004.

87. Guan B, Mao TL, Panuganti PK, Kuhn E, Kurman RJ, Maeda D, Chen E, Jeng YM, Wang TL and Shih IeM: Mutation and loss of expression of ARID1A in uterine low-grade endometrioid carcinoma. Am J Surg Pathol 35: 625-632, 2011.

88. He F, Li J, Xu JF, Zhang S, Xu Y, Zhao W, Yin Z and Wang X: Decreased expression of ARID1A associates with poor prognosis and promotes metastases of hepatocellular carcinoma. J Exp Clin Cancer Res 34: 47, 2015

89. Kim KJ, Jung HY, Oh MH, Cho H, Lee JH, Lee HJ, Jang SH and Lee MS: Loss of ARID1A expression in gastric cancer: Correlation with mismatch repair deficiency and clinicopathologic features. J Gastric Cancer 15: 201-208, 2015.

90. Mamo A, Cavallone L, Tuzmen S, Chabot C, Ferrario C, Hassan S, Edgren $\mathrm{H}$, Kalliomeni O, Aleynikova O, Przybytkowski E, et al: An integrated genomic approach identifies ARID1A as a candidate tumor-suppressor gene in breast cancer. Oncogene 31: 2090-2100, 2012.

91. Bosse T, ter Haar NT, Seeber LM, v Diest PJ, Hes FJ, Vasen HF, Nout RA, Creutzberg CL, Morreau H and Smit VT: Loss of ARID1A expression and its relationship with PI3K-Akt pathway alterations, TP53 and microsatellite instability in endometrial cancer. Mod Pathol 26: 1525-1535, 2013.

92.Lee D, Yu EJ, Ham IH, Hur H and Kim YS: AKT-inhibition is an effective treatment strategy in ARID1A-deficient gastric cancer cells. Onco Targets Ther 10: 4153-4159, 2017.

93. Samartzis EP, Gutsche K, Dedes KJ, Fink D, Stucki M and Imesch P: Loss of ARID1A expression sensitizes cancer cells to PI3K- and AKT-inhibition. Oncotarget 5: 5295-5303, 2014.

94. Guan B, Wang TL and Shih IeM: ARID1A, a factor that promotes formation of SWI/SNF-mediated chromatin remodeling, is a tumor suppressor in gynecologic cancers. Cancer Res 71: 6718-6727, 2011

95. Shain AH, Giacomini CP, Matsukuma K, Karikari CA, Bashyam MD, Hidalgo M, Maitra A and Pollack JR: Convergent structural alterations define SWItch/Sucrose NonFermentable (SWI/SNF) chromatin remodeler as a central tumor suppressive complex in pancreatic cancer. Proc Natl Acad Sci USA 109: E252-E259, 2012

96. Xiao W, Awadallah A and Xin W: Loss of ARID1A/BAF250a expression in ovarian endometriosis and clear cell carcinoma. Int J Clin Exp Pathol 5: 642-650, 2012.

97. Dykhuizen EC, Hargreaves DC, Miller EL, Cui K, Korshunov A, Kool M, Pfister S, Cho YJ, Zhao K and Crabtree GR: BAF complexes facilitate decatenation of DNA by topoisomerase II $\alpha$. Nature 497: 624-627, 2013.

98. Bochar DA, Wang L, Beniya H, Kinev A, Xue Y, Lane WS, Wang W, Kashanchi F and Shiekhattar R: BRCA1 is associated with a human SWI/SNF-related complex: Linking chromatin remodeling to breast cancer. Cell 102: 257-265, 2000.

99. Putra J and Suriawinata AA: Clinical significance of loss of ARID1A expression in colorectal and small intestinal carcinoma. Clin Transl Gastroenterol 6: e131, 2015.

100. Wang K, Kan J, Yuen ST, Shi ST, Chu KM, Law S, Chan TL, Kan Z, Chan AS, Tsui WY, et al: Exome sequencing identifies frequent mutation of ARID1A in molecular subtypes of gastric cancer. Nat Genet 43: 1219-1223, 2011.

101. Cho H, Kim JS, Chung H, Perry C, Lee H and Kim JH: Loss of ARID1A/BAF250a expression is linked to tumor progression and adverse prognosis in cervical cancer. Hum Pathol 44 $1365-1374,2013$.

102. Katagiri A, Nakayama K, Rahman MT, Rahman M, Katagiri H, Ishikawa M, Ishibashi T, Iida K, Otsuki Y, Nakayama S and Miyazaki K: Frequent loss of tumor suppressor ARID1 A protein expression in adenocarcinomas/adenosquamous carcinomas of the uterine cervix. Int J Gynecol Cancer 22: 208-212, 2012.

103. Ayhan A, Mao TL, Seckin T, Wu CH, Guan B, Ogawa H, Futagami M, Mizukami H, Yokoyama Y, Kurman RJ and Shih IeM: Loss of ARID1A expression is an early molecular event in tumor progression from ovarian endometriotic cyst to clear cell and endometrioid carcinoma. Int J Gynecol Cancer 22 1310-1315, 2012.

104. Yamamoto S, Tsuda H, Takano M, Tamai S and Matsubara O: Loss of ARID1A protein expression occurs as an early event in ovarian clear-cell carcinoma development and frequently coexists with PIK3CA mutations. Mod Pathol 25: 615-624, 2012
105. Yang L, Wei S, Zhao R, Wu Y, Qiu H and Xiong H: Loss of ARID1A expression predicts poor survival prognosis in gastric cancer: A systematic meta-analysis from 14 studies. Sci Rep 6: $28919,2016$.

106. Ahn DH, Javle M, Ahn CW, Jain A, Mikhail S, Noonan AM, Ciombor K, Wu C, Shroff R, Chen JL and Bekaii-Saab T: Next-generation sequencing survey of biliary tract cancer reveals the association between tumor somatic variants and chemotherapy resistance. Cancer 122: 3657-3666, 2016.

107. Balbás-Martinez C, Rodriguez-Pinilla M, Casanova A, Dominguez O, Pisano DG, Gómez G, Lloreta J, Lorente JA, Malats N and Real FX: ARID1 A alterations are associated with FGFR3-wild type, poor-prognosis, urothelial bladder tumors. PLoS One 8: e62483, 2013

108. Cho HD, Lee JE, Jung HY, Oh MH, Lee JH, Jang SH, Kim KJ, Han SW, Kim SY, Kim HJ, et al: Loss of tumor supressor ARID1A protein expression correlates with poor prognosis in patients with primary breast cancer. J Breast Cancer 18: 339-346, 2015.

109. Drage MG, Tippayawong M, Agoston TA, Zheng Y, Bueno R, Hornick JL, Odge RD and Srivastava A: Morphological features and prognostic significance of ARID1A-deficient esophageal adenocarcinomas. Arch Pathol Lab Med 141: 970-977, 2017

110. Faraj SF, Chaux A, Gonzales-Roibon N, Munari E, Ellis C, Driscoll T, Schoenberg MP, Bivalacqua TJ, Shih IeM and Netto GJ: ARID1A immunohistochemistry improves outcome prediction in invasive urothelial carcinoma of urinary bladder. Hum Pathol 45: 2233-2239, 2014.

111. Wang DD, Chen YB, Pan K, Wang W, Chen SP, Chen JG, Zhao JJ, Lv L, Pan QZ, Li YQ and Wang QJ: Decreased expression of the ARID1A gene is associated with poor prognosis in primary gastric cancer. PLoS One 7: e40364, 2012.

112. Wei XL, Wang DS, Xi SY, Wu WJ, Chen DL, Zeng ZL, Wang RY, Huang YX, Jin Y, Wang F, et al: Clinicopathologic and prognostic relevance of ARID1A protein loss in colorectal cancer. World J Gastroenterol 20: 18404-18412, 2014.

113. Wiegand KC, Hennesy BT, Leung S, Wang Y, Ju Z, McGahren M, Kalloger SE, Finlayson S, Stemke-Hale K, $\mathrm{Lu} Y$, et al: A functional proteogenomic analysis of endometrioid and clear cell carcinomas using reverse phase protein array and mutation analysis: Protein expression is histotype-specific and loss of ARID1A/BAF250a is associated with AKT phosphorylation. BMC Cancer 14: 120, 2014.

114. Cajuso T, Hänninen UA, Kondelin J, Gylfe AE, Tanskanen T, Katainen R, Pitkänen E, Ristolainen H, Kaasinen E, Taipale M, et al: Exome sequencing reveals frequent inactivating mutations in ARID1A, ARID1B, ARID2 and ARID4A in microsatellite unstable colorectal cancer. Int J Cancer 135: 611-623, 2014

115. Wiegand KC, Sy K, Kalloger SE, Li-Chang H, Woods R, Kumar A, Streutker CJ, Hafezi-Bakhtiari S, Zhou C, Lim HJ, et al: ARID1A/BAF250a as a prognostic marker for gastric carcinoma: A study of 2 cohorts. Hum Pathol 45: 1258-1268, 2014.

116. Zhang L, Wang C, Yu S, Jia C, Yan J, Lu Z and Chen J: Loss of ARID1A expression correlates with tumor differentiation and tumor progression stage in pancreatic ductal adenocarcinoma. Technol Cancer Res Treat 17: 1533034618754475, 2018

117. Tan ZX, Liu HJ and Hou B: Decreased expression of ARID1A is related to the poor prognosis of glioma patients. Int J Clin Exp Pathol 9: 2009-2014, 2016.

118. Nastase A, Teo JY, Heng HL, Ng CC, Myint SS, Rajaseragan V, Loh JL, Lee SY, Ooi LL, Chung AY, et al: Genomic and proteomic characterization of ARID1A chromatin remodeller in ampullary tumors. Am J Cancer Res 7: 484-502, 2017.

119. Itamochi H, Oumi N, Oishi T, Shoji T, Fujiwara J, Sugiyama T, Suzuki M, Kigawa J and Harada T: Loss of ARID1 A expression is associated with poor prognosis in patients with stage I/II clear cell carcinoma of the ovary. Int J Clin Oncol 20: 967-973, 2015.

120. Gui Y, Guo G, Huang Y, Hu X, Tang A, Gao S, Wu R, Chen C, Li X, Zhou L, et al: Frequent mutations of chromatin remodeling genes in transitional cell carcinoma of the bladder. Nat Genet 43: 875-878, 2011.

121. Jiao Y, Pawlik TM, Anders RA, Selaru FM, Streppel MM, Lucas DJ, Niknafs N, Guthrie VB, Maitra A, Argani, et al: Exome sequencing identifies frequent inactivating mutations in BAP1, ARID1A and PBRM1 in intrahepatic cholangiocarcinomas. Nat Genet 45: 1470-1473, 2013. 
122. Sausen M, Leary RJ, Jones S, Wu J, Reynolds PC, Liu X Blackford A, Parmigiani G, Diaz LA Jr, Papadopoulos N, et al: Integrated genomic analyses identify ARID1A and ARID1B alterations in the childhood cancer neuroblastoma. Nat Genet 45 12-17, 2013.

123. Illumina: An introduction to Next-Generation Sequencing Technology. Illumina, Inc., 2017. https://www.illumina.com/documents/products/illumina_sequencing_introduction.pdf.

124. Zhou X, Ren L, Meng Q, Li Y, Yu Y and Yu J: The next-generation sequencing technology and application. Protein Cell 6: $520-536,2010$.

125. Huang HN, Lin MC, Huang WC, Chiang YC and Kuo KT: Loss of ARID1A expression and its relationship with PI3K-Akt pathway alterations and ZNF217 amplification in ovarian clear cell carcinoma. Mod Pathol 27: 983-990, 2014.

126. Lai CR, Hsu CY, Chen YJ, Yen MS, Chao KC and Li AF: Ovarian cancers arising from endometriosis: A microenvironmental biomarker study including ER, HNF1ß, p53, PTEN, BAF250a, and COX-2. J Chin Med Assoc 76: 629-634, 2013.

127. Lowery WJ, Schildkraut JM, Akushevich L, Bentley R, Marks JR Huntsman D and Berchuck A: Loss of ARID1A-associated protein expression is a frequent event in clear cell and endometrioid ovarian cancers. Int J Gynecol Cancer 22: 9-14, 2012.

128. Maeda D, Mao TL, Fukayama M, Nakagawa S, Yano T, Taketani Y and Shih leM: Clinicopathological significance of loss of ARID1A immunoreactivity in ovarian clear cell carcinoma. Int J Mol Sci 11: 5120-5128, 2010

129. Wu RC, Ayhan A, Maeda D, Kim KR, Clarke BA, Shaw P, Chui MH, Rosen B, Shih leM and Wang TL: Frequent somatic mutations of the telomerase reverse transcriptase promoter in ovarian clear cell carcinoma but not in other major types of gynecologic malignancies. J Pathol 232: 473-481, 2014.

130. Yamamoto $S$, Tsuda $H$, Takano M, Tamai $S$ and Matsubara $O$ : PIK3CA mutations and loss of ARID1A protein expression are early events in the development of cystic ovarian clear cell adenocarcinoma. Virchows Arch 460: 77-87, 2012.

131. Murakami R, Matsumura N, Brown JB, Higasa K Tsutsumi T, Kamada M, Abou-Taleb H, Hosoe Y, Kitamura S, Yamaguchi $\mathrm{K}$, et al: Exome sequencing landscape analysis in ovarian clear cell carcinoma shed light on key chromosomal regions and mutation gene networks. Am J Pathol 187: 2246-2258, 2017.

132. Katagiri A, Nakayama K, Rahman MT, Rahman M, Katagiri H, Nakayama N, Ishikawa M, Ishibashi T, Iida K Kobayashi H, et al: Loss of ARID1A expression is related to shorter progression-free survival and chemoresistance in ovarian clear cell carcinoma. Mod Pathol 25: 282-288, 2012.

133. Samartzis EP, Samartzis N, Noske A, Fedier A, Caduff R, Dedes KJ, Fink D and Imesch P: Loss of ARID1A/BAF250a-expression in endometriosis: A biomarker for risk of carcinogenic transformation? Mod Pathol 25: 885-892, 2012.

134. McConechy MK, Ding J, Senz J, Yang W, Melnyk N, Tone AA, Prentice LM, Wiegand KC, McAlpine JN, Shah SP, et al: Ovarian and endometrial endometrioid carcinomas have distinct CTNNB1 and PTEN mutation profiles. Mod Pathol 27: 128-134, 2014.

135. Wu CH, Mao TL, Vang R, Ayhan A, Wang TL, Kurman RJ and Shih leM: Endocervical-type mucinous borderline tumors are related to endometrioid tumors based on mutation and loss of expression of ARID1A. Int J Gynecol Pathol 31: 297-303, 2012.

136. Choi JY, Han HH, Kim YT, Lee JH, Kim BG, Kang S and Cho NH: Ovarian clear cell carcinoma sub-typing by ARID1A expression. Yonsei Med J 58: 59-66, 2017.

137. Yokoyama Y, Matsushita Y, Shigeto T, Futagami M and Mizunuma H: Decreased ARID1A expression is correlated with chemoresistance in epithelial ovarian cancer. J Gynecol Oncol 25: 58-63, 2014

138. Cancer Genome Atlas Research Network, Kandoth C, Schultz N, Cherniack AD, Akbani R, Liu Y, Shen H, Robertson AG, Pashtan I, Shen R, et al: Integrated genomic characterization of endometrial carcinoma. Nature 497: 67-73, 2013.

139. Liang H, Cheung LW, Li J, Ju Z, Yu S, Stemke-Hale K, Dogruluk T, Lu Y, Liu X, Gu C, et al: Whole-exome sequencing combined with functional genomics reveals novel candidate driver cancer genes in endometrial cancer. Genome Res 22: 2120-2129, 2012.

140. Fadare O, Renshaw IL and Liang SX: Does the loss of ARID1A (BAF-250a) expression in endometrial clear cell carcinomas have any clinicopathological significance? A pilot assessment. J Cancer 3: 129-136, 2012
141. Fadare O, Gwin K, Desouki MM, Crispens MA, Jones HW III, Khabele D, Liang SX, Zheng W, Mohammed K, Hecht JL and Parkash V: The clinicopathologic significance of p53 and BAF-250a (ARID1A) expression in clear cell carcinoma of the endometrium. Mod Pathol 26: 1101-1110, 2013.

142. Werner HM, Berg A, Wik E, Birkeland E, Krakstad C, Kusonmano K, Petersen K, Kalland KH, Oyan AM, Akslen LA, et al: ARID1A loss is prevalent in endometrial hyperplasia with atypia and low-grade endometrioid carcinomas. Mod Pathol 26: 428-434, 2013.

143. Wiegand KC, Lee AF, Al-Agha OM, Chow C, Kalloger SE, Scott DW, Steidl C, Wiseman SM, Gascoyne RD, Gilks B and Huntsman DG: Loss of BAF250a (ARID1A) is frequent in high-grade endometrial carcinomas. J Pathol 224: 328-333, 2011.

144. Rahman M, Nakayama K, Rahman MT, Katagiri H, Katagiri A, Ishibashi T, Ishikawa M, Iida K and Miyazaki K Clinicopathologic analysis of loss of AT-Rich interactive domain $1 \mathrm{~A}$ expression in endometrial cancer. Hum Pathol 44 103-109, 2013.

145. Cornen S, Adelaide J, Bertucci F, Finetti P, Guille A, Birnbaum DJ, Birnbaum D and Chaffanet M: Mutations and deletions of ARID1A in breast tumors. Oncogene 31: 4255-4256, 2012

146. Zhang X, Zhang Y, Yang Y, Niu M, Sun S, Ji H, Ma Y, Yao G, Jiang Y, Shan M, et al: Frequent low expression of chromatin remodeling gene ARID1A in breast cancer and its clinical significance. Cancer Epidemiol 36: 288-293, 2012.

147. Zhao J, Liu C and Zhao Z: ARID1A: A potential prognostic factor for breast cancer. Tumour Biol 35: 4813-4819, 2014

148. Ünçel M, Diniz G, Aköz G, Ekin ZY, Sayhan S, Yardım S and Salimoğlu S: Loss of nuclear ARID-1A expressions is associated with hormone receptor status in breast cancers. Eur J Breast Health 15: 125-129, 2019.

149. Momozawa Y, Iwasaki Y, Parsons MT, Kamatani Y, Takahashi A Tamura C, Katagiri T, Yoshida T, Nakamura S, Sugano K, et al: Germline pathogenic variants of 11 breast cancer genes in 7,051 Japanese patients and 11,241 controls. Nat Commun 9: 4083, 2018.

150. Rajendran KB and Deng C: Characterization of potential driver mutations involved in human breast cancer by computational approaches. Oncotarget 8: 50252-50272, 2017.

151. Zang ZJ, Cutcutache I, Poon SL, Zhang SL, McPherson JR, Tao J, Rajasegaran V, Heng HL, Deng N, Gan A, et al: Exome sequencing of gastric adenocarcinoma identifies recurrent somatic mutations in cell adhesion and chromatin remodeling genes. Nat Genet 44: 570-574, 2012

152. Abe H, Maeda D, Hino R, Otake Y, Isogai M, Ushiku AS, Matsusaka K, Kunita A, Ushiku T, Uozaki H, et al: ARID1A expression loss in gastric cancer: Pathway-dependent roles with and without Epstein-Barr virus infection and microsatellite instability. Virchows Arch 461: 367-377, 2012.

153. Han N, Kim MA, Lee HS and Kim WH: Loss of ARID1A expression is related to gastric cancer progression, Epstein-Barr Virus infection, and mismatch repair deficiency. Appl Immunohistochem Mol Morphol 24: 320-325, 2016.

154. Ibarrola-Villava M, Llorca-Cardeñosa MJ, Tarazona $\mathrm{N}$, Mongort C, Fleitas T, Perez-Fidalgo JA, Roselló S, Navarro S, Ribas G and Cervantes A: Deregulation of ARID1A, CDH1, cMET and PIK3CA and target-related microRNA expression in gastric cancer. Oncotarget 6: 26935-26945, 2015.

155. Kim YB, Ham IH, Hur H and Lee D: Various ARID1A expression patterns and their clinical significance in gastric cancers. Hum Pathol 49: 61-70, 2016.

156. Imielinski M, Berger AH, Hammerman PS, Hernandez B, Pugh TJ, Hodis E, Cho J, Suh J, Capelletti M, Sivachenko A, et al: Mapping the hallmarks of lung adenocarcinoma with massively parallel sequencing. Cell 150: 1107-1120, 2012.

157. Fujimoto A, Totoki Y, Abe T, Boroevich KA, Hosoda F, Nguyen HH, Aoki M, Hosono N, Kubo M, Miya M, et al: Whole-genome sequencing of liver cancers identifies etiological influences on mutation patterns and recurrent mutations in chromatin regulators. Nat Genet 44: 760-764, 2012

158. Guichard C, Amaddeo G, Imbeaud S, Ladeiro Y, Pelletier L, Maad IB, Calderaro J, Bioulac-Sage P, Letexier M, Degos F, et al: Integrated analysis of somatic mutations and focal copy-number changes identifies key genes and pathways in hepatocellular carcinoma. Nat Genet 44: 694-698, 2012

159. Streppel MM, Lata S, DelaBastide M, Montgomery EA, Wang JS, Canto MI, Macgregor-Das AM, Pai S, Morsink FH, Offerhaus GJ, et al: Next-generation sequencing of endoscopic biopsies identifies ARID1A as a tumor-suppressor gene in Barrett's esophagus. Oncogene 33: 347-357, 2014. 
160. Lee SY, Kim DW, Lee HS, Ihn MH, Oh HK, Park DJ, Kim HH and Kang SB: Loss of AT-rich interactive domain 1A expression in gastrointestinal malignancies. Oncology 88: 234-240, 2015.

161. Sen M, Wang X, Hamdan FH, Rapp J, Eggert J, Kosinsky RL, Wegwitz F, Kutschat AP, Younesi FS, Gaedcke J, et al: ARID1A facilitates KRAS signaling-regulated enhancer activity in an AP1-dependent manner in colorectal cancer cells. Clin Epigenet 11: 92, 2019.

162. Guo G, Sun X, Chen C, Wu S, Huang P, Li Z, Dean M, Huang Y, Jia W, Zhou Q, et al: Whole-genome and whole-exome sequencing of bladder cancer identifies frequent alterations in genes involved in sister chromatid cohesion and segregation. Nat Genet 45: 1459-1463, 2013.

163. Treon SP, Xu L, Yang G, Zhou Y, Liu X, Cao Y, Sheehy P, Manning RJ, Patterson CJ, Tripsas C, et al: MYD88 L265P somatic mutation in Waldenström's macroglobulinemia. N Engl J Med 367: 826-833, 2012.

164. Giulino-Roth L, Wang K, MacDonald TY, Mathew S, Tam Y, Cronin MT, Palmer G, Lucena-Silva N, Pedrosa F, Pedrosa M, et al: Targeted genomic sequencing of pediatric Burkitt lymphoma identifies recurrent alterations in antiapoptotic and chromatin-remodeling genes. Blood 120: 5181-5184, 2012
165. Weaver IC, Korgan AC, Lee K, Wheeler RV, Hundert AS and Goguen D: Stress and the emerging roles of chromatin remodeling in signal integration and stable transmission of reversible phenotypes. Front Behav Neurosci 11: 41, 2017.

166. Bitler BG, Wu S, Park PH, Hai Y, Aird KM, Wang Y, Zhai Y, Kossenkov AV, Vara-Ailor A, Rauscher FJ III, et al: ARID1A-mutated ovarian cancers depend on HDAC6 activity. Nat Cell Biol 19: 962-973, 2017.

167. Bitler BG, Aird KM, Garipov A, Li H, Amatangelo M, Kossenkov AV, Schultz DC, Liu Q, Shih IeM, Conejo-Garcia JR, et al: Synthetic lethality by targeting EZH2 methyltransferase activity in ARID1A-mutated cancers. Nat Med 21: 231-238, 2015.

c) (7) $\ominus$ This work is licensed under a Creative Commons EY NC NO Attribution-NonCommercial-NoDerivatives 4.0 International (CC BY-NC-ND 4.0) License. 